\title{
DEATH AND THE MEDIA: INFECTIOUS DISEASE REPORTING DURING THE HEALTH TRANSITION
}

\author{
Dora L. Costa and \\ UCLA Department of Economics, 9272 Bunche Hall, Los Angeles, CA 90095-1477 and NBER, \\ costa@econ.ucla.edu \\ Matthew E. Kahn \\ USC, Department of Economics, Los Angeles, CA 90089, kahnme@usc.edu
}

\begin{abstract}
In the late 19th Century, cities in Western Europe and the United States suffered from high levels of infectious disease. Over a 40 year period, there was a dramatic decline in infectious disease deaths in cities. As such objective progress in urban quality of life took place, how did the media report this trend? At that time newspapers were the major source of information educating urban households about the risks they faced. By constructing a unique panel data base, we find that news reports were positively associated with government announced typhoid mortality counts and the size of this effect actually grew after the local governments made large investments in public water works to reduce typhoid rates. News coverage was more responsive to unexpected increases in death rates than to unexpected decreases in death rates.
\end{abstract}

Accurate media reports inform the electorate and increase government accountability, leading to greater expenditures on calamity relief and to less corruption (e.g., Besley and Burgess 2002; Besley and Pratt 2006; Larreguy, Marshall, and Snyder 2014; Strömberg 2015a). But how does the media report news? We investigate this question by examining how the media reacted to changes in typhoid death rates in the United States between 1890 and 1932. In the early twentieth century, typhoid fever, a water-borne illness for which there was no cure and which killed 10-20\% of its victims, ravaged US cities. Typhoid fever death rates fell sharply after cities invested in expensive clean water infrastructure (Alsan and Goldin 2015; Cutler and Miller 2005; Troesken 1999), with declines in typhoid fever accounting for nearly half of the total mortality reductions in major US cities between 1900 and 1936 (Cutler and Miller 2005). Although the worldwide fatality rate for typhoid fever has fallen to $1 \%$, the annual global burden is 12 million cases (John, Van Aart, and Grassly 2016). Children in urban areas on the Indian subcontinent are particularly affected. In New Delhi's urban slums, the incidence rate among children younger than age 5 is 29 per 1000 and in urban slums in Bangladesh the incidence rate among preschool-aged children is 18.7 per 1000 (Wain et al. 2015) at a time of growing drug-resistance.

In the time period we study, newspaper readership was rising in US cities, technological progress in newsprint and the newspaper industry was lowering costs, and newspapers were 
investing heavily in staff. Increases in the scale and competiveness of newspapers led to more informative and less partisan reporting of corruption scandals (Gentzkow, Glaeser, and Goldin 2006). At the same time, competition led newspapers to sensationalize stories, most notably in the run-up to the Spanish-American War. Newspapers also ran campaigns, such as the one lobbying for the acceptance and public provison of diphtheria antitoxin in New York City (Hammond 244-245). Thus a focus on the shocking or editors' desire to run campaigns can lead to coverage that does not match the statistics. Coverage also may not match the statistics if consumers want to respond immediately to certain types of news, for example, if bad news requires quick action whereas good news does not.

We study how newspapers treated the major public health issue of the day by creating a database of weekly counts of articles mentioning typhoid from major US newspapers from 1890 to 1932 and documenting how news reports responded to weekly typhoid death rates in 6 US cities. In this time period newspapers were the major source of information educating urban households about the disease risks they faced. We find that news reports were positively associated with mortality rates, thus suggesting that newspapers were informing their readers about the mortality risks they faced. Our results are consistent with the finding that in recent times the number of newspaper articles on topics of concern to consumers such as crime, inflation, and disease closely track self-reports of concern in polls and ameliorative actions by consumers (Loewenstein and Mather 1990). However, we also find that coverage did not systematically track death rates. Controlling for falling death rates, news coverage fell after the clean water interventions. In addition, the responsiveness of news reporting to changes in typhoid mortality rates was lower before the clean water interventions compared to after the clean water interventions, is consistent with the observation that famines attract more press attention than chronic malnutrition (Ram 1991). Typhoid news coverage also was more responsive to unexpected increases in death rates than to unexpected decreases in death rates, a result that is consistent with findings that the media are more likely to report bad economic news (e.g., Soroka 2006).

\section{Demand and Supply of Public Health News}

Why did people demand typhoid information? Information would allow consumers to take measures to protect themselves against this contagious disease and to lobby for the public provision of clean water. Typhoid spread primarily through drinking water contaminated with the wastes of infected individuals. Prior to clean water interventions, roughly $90 \%$ of typhoid cases were water-borne (Beach et al. 2015). Other modes of transmission were direct contact with a contaminated privy, with the wastes of a typhoid patient, with food prepared by a typhoid carrier, or indirect contact with a contaminated privy through flies. Precautions individuals could take included bringing water to a roiling boil, using individual water filters, pasteurizing milk, thoroughly cooking all vegetables, peeling fruit, disinfecting privies and homes, and sealing privies and homes from flies. ${ }^{1}$ Such precautions were easier for the wealthier who had both the knowledge and the servants for these tasks, thus leading to lower mortality rates in richer and whiter wards (Costa and Kahn 2015; Kesztenbaum and

\footnotetext{
${ }^{1}$ The typhoid vaccine developed at the end of the nineteenth century provided a moderate level of protection but it led to fever and malaise and was unpopular even among health authorities (Levine 2003).
} 
Rosenthal 2011). Nonetheless even the wealthy faced higher mortality risks - they could not be certain that all drinking, bathing, and dishwashing water had been boiled whether in the home, restaurants, or hotels nor could they be certain about the cleanliness of their fruits and vegetables. $^{2}$

Why would the media provide typhoid information? If consumers wanted this information, competition among different media outlets could lead to its provision (Gentzkow and Shapiro 2008; cf. Strömberg 2015b). Alternatively, editors' wish to run campaigns and spur citizens to lobby for clean water would lead to a focus on public health issues. ${ }^{3}$ Consumer and editorial interests could thus converge to build a political coalition for financing clean water interventions.

The primary challenges faced by cities in adopting clean water technologies were financial and legal, and were not related to political ideology (a point we revisit in section 6). ${ }^{4}$ The infrastructure for obtaining clean water was expensive, requiring a developed municipal bond market (Cutler and Miller 2006), the creation of water boards, and changes to state constitutions. For instance, Philadelphia voted in 1897 for filtration but the estimated cost rose from 3-4 million to 8-10 million dollars. Because there was not enough money to provide filtered water for the entire city, there was opposition from those in areas that would not receive it. A bond issue of $\$ 12$ million approved in 1899 enabled the city to provide water for everyone (McCarthy 1987). Another example is the building of the Ashokan Reservoir and Catskill Dam, a ten year project, requiring New York State to amend its constitution in 1905 by popular vote to except from the constitutional debt limit of municipalities "debts incurred by the city of New York after the 1st day of January, 1904 ... for the supply of water" (Kunz 1917: 79-83).

There are several potential factors working against the provision of typhoid information. Breaking news will crowd-out typhoid reporting (e.g., see Eisensee and Strömberg 2007 on natural disasters and other news events). A more journalistically newsworthy article should receive more coverage (Prat and Strömberg 2013). Just as famines receive more attention than endemic hunger (Ram 1991) so too might typhoid receive more attention when it is rare than when it is common. In the middle of a large outbreak (and these happened only when levels of typhoid were high), there may be diminishing marginal returns to yet another story about typhoid. Journalists, for career reasons, may disproportionately pursue the stories that will be published on the front page (Baron 2006). In addition, local boosterism may deter newspapers from publishing stories that might tarnish their city's image.

The desire to entertan readers could work either for or aganst the provision of typhoid information. Entertaining stories could crowd out typhoid reporting (see Hamilton 2004 on

\footnotetext{
${ }^{2}$ As a report on Chicago's 1902 epidemic noted, "The river wards cannot be isolated from the other resident portions of the town. In this district are the stables of various large firms whose delivery wagons are sent throughout the city and suburbs; many of the teams doing city contract work are kept here; the peddlers' carts which carry fruit and vegetables in every direction within a day's journey start in large numbers from this region and their supplies are stored here" (Gernon, Hamilton, and Hull House 1903).

3 Anderson and McLaren (2012) emphasize the role of owners' interests in media coverage.

${ }^{4}$ Deaton(2013) has emphasized the role of the franchise in clean water investments but the US had universal male suffrage, even in the South where African-Americans were disenfranchised, whites favored clean water expenditures, particularly when they lived in close proximity to African-Americans, suggesting that fear of contagion led to public spending (Troesken 2004).
} 
the substitution of entertainment for political reporting), but by turning statistics into stories the media can make acquiring information less costly for consumers (Dyck, Moss, and Zingales 2013). Our reading of news articles in The New York Times shows that typhoid articles ranged over a wide variety topics, probably because of the widespread impact of typhoid on daily life. Between 1900 and 1930, roughly 13\% of all typhoid mentions in The New York Times were in obituaries and another $17 \%$ in editorials and letters to the editor. Sixty-one percent were news articles. The news stories included accounts of typhoid outbreaks and discussions of sources of the outbreaks, health department recommendations and news, sensationalist stories (e.g., a broker's wife dying in a three story fall while the broker was sick with typhoid or a woman with typhoid jumping from a ship), charitable appeals for the neediest fund, society news (e.g., Vanderbilt was back in town and looking better after typhoid), and sports news (e.g., a pitcher returned after being ill with typhoid.)

\subsection{Hypotheses}

We hypothesize that typhoid reporting should follow disease trends in the elite newspapers. These were the newspapers with the staff for exhaustive coverage and whose readers would have the knowledge and means to engage in self-protection behavior and to lobby effectively for cleaner water. Consistent with Prat and Strömberg's (2013)'s model, elite newspapers should provide information on disease trends because this was of interest to their customers. We expect that the more stories a newspaper printed, the more likely they were to publish a story about typhoid. We hypothesize that competition for circulation could lead either to more or less reporting, depending consumers' demand for typhoid information compared to other types of stories.

We expect that there will be systematic deviations from disease trends in news reporting. Prat and Strömberg's (2013) predict too much attention may be devoted to news stories that are of particular interest to larger groups or groups more valuable to advertisers and to news stories that are considered newsworthy. Once cities clean up the water supply, there may be less reporting because there is less need for government action and private self-protection measures. However, reporting could increase because newspapers no longer face reader fatigue from typhoid stories, because sensationalism will lead newspapers to focus on lowrisk causes of death (as found in Frost, Frank, and Maibach 1997), or because selfprotection, which the elite were better at, become more important than public health interventions. We also expect that "bad" news will receive more attention than "good" news. For example, in examining inflation expectations, Carroll (2003) found that not only did the volume of news matter, but also news that represented a sharp and negative break from the past. Consumers may be more interested in bad news because it requires more immediate action or because individuals care more about loss in utility than gain (Kahneman and Tversky 1979).

\section{Econometric Specifications}

As discussed above, we seek to document whether the urban media was responsive to changes in "objective reality". Put simply, when the death count increased from infectious disease, did the media cover the story? We then seek to test whether the media's response 
differs before and after the major local public health interventions. Controlling for death rates, did reporting fall after the interventions? Is reporting more responsive to increases or decreases in death rates after the interventions? To study this, we estimate count models of how the number of weekly news reports (r) depends on current weekly death rates (d), the clean water intervention (I), and the interaction between the clean water intervention and the death rate. In a linear form, we have

$$
r=\gamma_{1} d+\gamma_{2} I+\gamma_{3}(d \times I) .
$$

The specification allows for an increase in reporting after the intervention if death rates increase.

We also hypothesize that "bad" news would receive more attention than "good" news. Thus the number of weekly news reports depends on the death rate (d) and on whether this change is "bad news",

$$
r=\delta_{1} d+\delta_{2} \text { (Dummy=1 if bad news). }
$$

We adopt a simple forecasting model to determine whether "good" and "bad" news are treated asymmetrically. Urban households having read past newspapers are aware of past broad trends in typhoid death and case rates. The media in supplying news knows that a deviation from past trends, particularly an unexpected increase in deaths, will interest its readers. For example during a time when typhoid death rates are declining, it may not be "new news" that typhoid death rates are low. In such a setting, new "bad news" would be if the typhoid death rate in that week is larger than would be expected given the recent time trend. We test whether the media was more responsive to such "unexpected bad news". We operationalize our explanatory variable measuring "new news", by treating a surprise in death rates as a deviation from a two year rolling average of past city death rates. Thus, in current time period $i$, the deviation from death rate trend (D) for each city is

$$
D_{i}^{0}=d_{i}-\hat{d}_{i}
$$

where $\hat{d}_{i}$ is the predicted death rate (from a two year rolling average) and $d_{i}$ is the death rate. Our "bad" news dummy is equal to one if this deviation is positive.

We specify the relationship between the count of articles and death rates or unexpected deviations in death rates using a negative zero inflated binomial model to account for excess zeros and over-dispersion. Assume that the observed count of articles $y_{i}$ is the product of two latent variables, $z_{i}$ and $y_{i}^{*}$,

$$
y_{i}=z_{i} y_{i}^{*}
$$

where $z_{i}$ is binary variable with values 0 or 1 , and $y_{i}^{*}$ has a negative binomial distribution. Then, 


$$
\begin{gathered}
\operatorname{Pr}\left(y_{i}=0\right)=\operatorname{Pr}\left(z_{i}=0\right)+\operatorname{Pr}\left(z_{i}=1, y_{i}^{*}=0\right)=q_{i}+\left(1-q_{i}\right) f(0) \\
\operatorname{Pr}\left(y_{i}=k\right)=\left(1-q_{i}\right) f(k), k=1,2, \ldots
\end{gathered}
$$

where $q_{i}$ is the probability of no article and $f(\cdot)$ is the negative binomial probability distribution for $y_{i}^{*}$. We model the binary process $z_{i}$ using a logit model. We perform Vuong tests to determine if the excess number of zeros leads us to prefer a zero-inflated negative binomial model to a standard negative binomial model (a statistically significant statistic suggests yes). If we reject the negative binomial model in favor of the zero-inflated negative binomial model, we will then test whether the dispersion parameter (a) is 0 (or the logarithm of $a$ is negative infinity). A statistically insignificant dispersion parameter suggests that we instead should be using a Poisson model. We estimate our zero-inflated negative binomial regression models with robust standard errors, clustered on the city-year.

We specify the logit part of the zero-inflated negative binomial regression as $\operatorname{Pr}(y=0)=L($ dummy $=1$ if news event, dummy $=1$ if holiday week, percentage of circulation $)$

We also include city, week, and year fixed effects when we examine pre- and postintervention reporting. We do not include week fixed effects when we investigate "bad" news effects because otherwise we could not achieve convergence.

We specify the negative binomial part of the zero-inflated binomial regression model in two different ways. In our first specification, Equation 2 below, we examine differential reactions to typhoid death rates before and after the clean water interventions. Our specification includes typhoid death or case rates (d), two clean water interventions $\left(I_{1}\right.$ and $\left.I_{2}\right)$, and interactions between deaths rates and the clean water interventions.

$$
\operatorname{Pr}(y=k)=F\left(d, I_{1}, I_{2}, I_{1} \times d, I_{2} \times d, \text { number of total articles }\right)
$$

We include city and week fixed effects. We also present estimates with year fixed effects but because we have only six cities and because our dummy variables for interventions depend on the year (and many of our interventions occur at similar times), we have colinearity with our intervention variables. Our preferred specification therefore includes only city and week fixed effects.

When we examine the impact of "bad" news our specification of the count part of the regression becomes 


$$
\operatorname{Pr}(y=k)=F(d, \text { Dummy }=1 \text { if "bad" news }) \text {, number of total articles })
$$

where $d$ is the death rate and "bad" news, as specified above, is a positive deviation from a 2 year rolling mean of previous death rates.

We present average marginals of death or case rates and the interaction of death and case rates for all of our regressions, following the procedures outlined in Lietgöb (2014). Thus when the inverted link function $E(y \mid x)$, is $\exp \left(\gamma_{1} d+\gamma_{2} I_{1}+\gamma_{3} I_{2}+\gamma_{4}\left(d \times I_{1}\right)+\gamma_{5}\left(d \times I_{2}\right)\right)$, we present estimates of $\frac{\partial E(y \mid x)}{\partial d}, \frac{\partial E(y \mid x)}{\partial I_{1} \partial I_{2}}, \frac{\partial E(y \mid x)}{\partial d \partial I_{1}}$, and $\frac{\partial^{3} E(y \mid x)}{\partial d \partial I_{1} \partial I_{2}} \cdot 5$ When we examine "bad" news we present estimates of $\frac{\partial E(y \mid x, \text { no "bad" news })}{\partial d}$ and $\frac{\partial E(y \mid x, \text { "bad" news })}{\partial d}$.

\section{Data}

We created a panel data set from newspaper articles and from weekly typhoid death and case rates for New York City, Baltimore, Boston, Chicago, Washington DC, and Philadelphia. Weekly deaths and cases for New York City are from our digitization of Emerson and Hughes (1941), which provides continuous data from 1890 until 1938. Weekly deaths and cases for our other cities are from Project Tycho (https://www.tycho.pitt.edu/), which digitized data from the weekly national publication, Public Health Reports. These data are still incomplete, with many cities still missing weeks; the number of cases only begins to be published in 1906 and both deaths and cases are more likely to be missing once typhoid deaths have fallen to close to zero. Deaths are available up to 1932. (Data on other infectious disease are available from our digitization of Emerson and Hughes (1941) but are often still unavailable from the Project Tycho data.) We used data from the published censuses of population to estimate yearly city populations (adjusted for city annexations of neighboring communities) and thus yearly death and case rates.

We obtained daily counts of the total number of newspaper articles and the number of newspaper articles mentioning typhoid and also typhoid and the city using mechanized searches of the New York Times, the Baltimore Sun, the Boston Globe, the Chicago Tribune, the Washington Post and the Philadelphia Inquirer. ${ }^{6}$ Appendix B, which provides information on the total number of dailies within each city and the percentage of circulation of each newspaper, suggests that Manhattan was the most competitive market and Baltimore one of the least. (For a comparison of mechanized and manual searches see Appendix C.) The newspapers in our data base were the major "serious" newspapers within each city (with the exception of the New York Herald Tribune their rivals have not been digitized and

\footnotetext{
5 In a non-linear model interaction effects are dependent on covariates and thus differ across individuals and may even have different signs for individuals. We present mean interaction effects. In no cases did we obtain different signs of the interaction effects for individuals.

${ }^{6}$ The first five newspapers are available from Proquest Historical Newspapers. The Philadelphia Inquirer is available from Readex America's Historical Newspapers. We also investigated NewspaperArchive.com but judged this resource to yield incomplete digitizations. For example, searches in NewspaperArchive.com of typhoid mentions in the New York Times and Boston Globe between 1890 and 1930 yielded 3,979 and 431 articles, respectively, compared to 8,229 and 5,356, respectively, using Proquest.
} 
indexed). We also collected daily counts of the New York Tribune, later known as the New York Herald Tribune, to examine political slant and of the Baltimore Afro-American and the American Hebrew and Jewish Messenger to investigate minority newspapers. However, we do not use these newspapers in our primary regressions. As we later discuss, typhoid coverage in the New York Herald Tribune was very similar to that in the New York Times and minority newspapers specialized in minority issues, not in daily news. We aggregated our daily counts to the weekly level. Reports include all types of news, including reports from local public health officials, stories of outbreaks, society news, obituaries of wellknown individuals, editorials, and appeals to charity.

Cities had to have both digitized and indexed newspapers and good weekly typhoid death data to be included in our panel data set. ${ }^{7}$ Our final panel data set has data for New York City for all weeks for 1890-1932, and, with some weeks missing, for Chicago for 18961932, Baltimore for 1900-1932, Boston for 1890-1932, Philadelphia for 1901-1922, and Washington DC for 1890-1932. We top-coded the number of weekly typhoid articles at 25 and the number of local typhoid articles at 18 to facilitate convergence (this affects only about $0.2 \%$ of the sample). We also created dummy indicators for a holiday during that specific week and for a major news event that week. What constituted a major news event was a judgement call. Recurring events such as the day after elections and the World Series were labeled major news events, as were outbreaks of war and major war events, natural disasters, New York City ticker tape parades and the events meriting these parades, new world records, and famous trials, murders, and kidnappings. Lastly, we calculated the percentage of total circulation by year for each newspaper from Gentzkow, Shapiro, and Sinkinson (2014), interpolating for missing years.

\section{Typhoid Case and Death Rates}

The major interventions in each of our cities (see Table 1) take the form either of cleaning up the water supply obtained from the nearby river through chlorination or filtration or of obtaining new, clean sources of water. ${ }^{8}$ For each city we could identify two interventions from Cutler and Miller (2005) for Chicago, Baltimore, and Philadelphia and from histories of local water supply systems for New York City, Boston, and Washington, DC. (Although we could identify a third for New York City, the effect of this intervention on death rates was negligible.)

Figure 1, which also shows missing data, and Table 2 suggest that the interventions were effective in lowering typhoid mortality and case rates. In the sample as a whole, typhoid death rates per 100,000 were 0.8 prior to any intervention, 0.4 after the first intervention but before the second, and 0.1 after the second intervention. Prior to the first intervention, death rates per 100,000 varied widely across cities with highs of 1.0 and 1.5 in Philadelphia and Washington, DC, respectively, and a low of 0.4 in New York City. (Both Philadelphia and Washington DC drew their water from contaminated rivers whereas in New York City some

\footnotetext{
${ }^{7}$ Because the Project Tycho data are still incomplete even when partial information is available for cities, the restriction to cities with good weekly typhoid death data excludes most of the newspapers available in Proquest.

${ }^{8}$ Chlorination and filtration were not redundant. Chlorination does not work well in water that is filled with sediment because the dirt particles absorb the chlorine. Philadelphia's water was so muddy, it needed preliminary filters to keep out the dirt (McCarthy 1987).
} 
but not all areas had access to clean water.) After both interventions, death rates per 100,000 varied from a high of 0.2 in Baltimore to a low of 0.03 in New York City. Case rates also fell after an intervention and converged across cities. Clean water interventions were statistically significant negative predictors of death rates, controlling for a year trend (see Appendix D). Fatality rates, however, did not fall sharply. For example, in both New York City and Boston, there were roughly 24 and 21 deaths per 100 cases, respectively, between 1900 and 1909 and 15 and 19 deaths per 100 cases, respectively, after 1919.

\section{Results: Death and the Media}

Figure 2, which shows smoothed plots of typhoid death rates and of the percentage of typhoid articles, suggests that while on the whole reports of typhoid followed mortality patterns, with more reporting in a high mortality regime than in a low mortality regime, an increase in city death rates led to more news reports in a low than in a high mortality regime. For example, in New York City, the up-tick in typhoid mortality rates in the 1920s is associated with an increase in news reports that is greater than the increase in the early 1890s when typhoid mortality rates spiked up higher. The increases in reporting that are not related to city death rates were often associated with world events such as concern over typhoid epidemics during the Spanish-American War and World War I.

We find no evidence of slant in typhoid reporting based on political affiliation among the two major newspapers in New York City (see Figure 3). The New York Times between 1890 and 1932 endorsed 9 Democrats and only 2 Republicans (McKinley and Taft) for president. In contrast, the New York Tribune, which became the New York Herald Tribune in 1924, was staunchly Republican. Our reading of editorials and other articles detects no differences in tone. Both newspapers favored public water filtration. Table 3 examines the number of articles in each newspapers mentioning typhoid and potential causes and proscriptions (water, water and filter/chlorinate, water and boil, milk, milk and pasteurize, carriers, and oysters) before and after the interventions. The fraction of typhoid articles in each time period mentioning water ranged from 28 to $30 \%$ in the Herald Tribune and 27 to $28 \%$ in the New York Times. The fraction of articles mentioning water and filtration/chlorination was roughly similar. After the interventions, the fraction of articles mentioning typhoid carriers increased, but the focus still remained on water. The newspaper that was slanted was the Christian Science Monitor, first published in Boston in $1908 .{ }^{9}$ Whereas the Boston Globe published 1,446 items about typhoid out of 1,022,682 total between 1908 and 1918, the Christian Science Monitor published 15 out of 1,088,269. ${ }^{10}$

We find that reporting among newspapers whose target audience was a minority group did not follow death rates (see Figure 4), probably because the newspapers specialized in news directly related to minorities and competed with the elite newspapers through product differentiation (Mullainathan and Shleifer 2005). This targeting of news reporting in specialized newspapers mirrors research findings in urban economics that niche products arise when there is sufficient local market scale to cover fixed costs (Waldfogel 2008).

\footnotetext{
${ }^{9}$ Christian Scientists believe in prayer not medicine or public health.

${ }^{10}$ Under-reporting of disease was not limited to typhoid. Between 1917-20, the Christian Science Monitor published 83 articles about influenza compared to the 1,771 published by the Boston Globe.
} 
Figure 4 shows that whereas reporting trends in the New York Times coincided with death rate trends, those in the American Hebrew and Jewish Messenger, also based in New York, did not. Even though white and non-white death rates in Baltimore followed the same pattern ${ }^{11}$, reporting by the Sun coincided with death rate trends, whereas reporting by the Afro-American did not.

Our regression results indicate that typhoid reporting is responsive to death rates, falls after both interventions controlling for death rates under any plausible death rate increases, and that the response to death rates is greater after the interventions than before (see Table 4). ${ }^{12}$ Our first specification, which includes both city and week fixed effects in the count part of the regression, indicates that prior to any intervention, a half standard deviation increase in post first intervention typhoid death rates $(0.141)$ leads to an increase of 0.03 in the differences of the logarithms of the expected count of typhoid articles $(=0.141 \times 0.247)$. After both interventions, this half standard deviation increase of 0.141 in death rates yields an additional increase in the difference of the logarithms of the expected count of typhoid articles of $0.08(=0.141 \times 0.536)$. We observe a similar pattern when we examine local typhoid articles (specification 3). Our results were robust to excluding the Spanish-American War, World War I, and the influenza pandemic (results now shown). When we include year fixed effects (specifications 2 and 4), we face colinearity problems and find that responses to death rates are statistically significantly greater only after the first intevention and before the second one.

Table 5, which gives the marginal effects, allows us to assess the magnitude of media responsiveness to death rates and the interventions. In our first specification, a half standard deviation increase of 0.141 in death rates increases the number of all typhoid articles by $0.209(=0.141 \times 1.479)$. The first intervention has a small and statistically insignificant effect on the relationship between death rates and typhoid articles. But, the second intervention increases this relationship by $0.33(0.141 \times 2.339)$. a $10 \%$ increase relative to the mean number of articles. Our third specification shows that prior to the intevention a half standard deviation increase in death rates raises the number of local typhoid articles by $0.06(=0.141 \times$ 0.447), a five percent increase relative to the mean number of local articles. After the second intervention, the number of local typhoid articles increases by $0.17(=0.141 \times 1.239)$, a $13 \%$ increase. When we include year fixed effects (specifications 2 and 4), although there is no statistically significant change after the interventions, the magnitude of the effects suggests that after the interventions, the media were twice as responsive to typhoid death rates in writing local articles.

We find that the media respond more to "bad" than to "good" news. Our specification for "bad" news is based on deviations from a 2 year rolling mean of past death rates. Both all and local typhoid reporting increases with death rates, but when the news is "bad" there is more reporting (see Table 6). ${ }^{13}$ The marginals given in the table show that when death rates

\footnotetext{
11 Estimated by the authors from published yearly mortality reports.

12 Although a large enough increase in death rates after the interventions could increase typhoid reporting, we do not observe death rates of a large enough magnitude that would lead to an increase in reporting in three out of our four specifications. While reporting could increase in our second specification after the interventions, death rates would need to increase by six standard deviations from the mean.
} 
increase, a half standard deviation increase in death rates leads to a statistically significant increase of $0.13(=0.141 \times 0.949)$ when there is no "bad" news and a statistically significant increase of $0.18(=0.141 \times 1.278)$ when the news is bad. Relative to the mean number of typhoid articles, these are increases of 4 and 5\%, respectively. When we examined local articles we found that no "bad" news led to an increase of $0.05(=0.141 \times 0.325)$, an increase of $4 \%$ relative to the mean, whereas "bad" news produced an increase of $0.08(=.141 \times$ $0.554)$, an increase of $6 \%$ relative to the mean.

More overall reporting led to more typhoid reporting: the greater the number of total item published by the paper, the greater the number of typhoid articles. A large news event displaced all typhoid reporting, with a statistically significant effect, in some of our specifications. Because large news events such as wars or natural disasters were associated with typhoid outbreaks or fear of typhoid outbreaks, news events could conceivably lead to more typhoid reporting. We found no effect of holidays on news reports. Holidays could either have displaced typhoid reporting or could have increase it if typhoid articles could be written ahead of time or if appeals to charity are more likely during holidays.

Newspaper characteristics did not matter, perhaps because we are examining the elite newspapers. On the whole, a newspaper's market share (as measured by the percentage of circulation) had a statistically insignificant effect on the number of articles. We did not obtain better results by using the number of dailies (results not shown).

We found no evidence that newspapers were more likely to report on typhoid when their political affiliation was different from that of the current mayor (results not shown). Our results contrast with Puglisi's (2011) finding that from 1946 to 1997, the New York Times gave more coverage to Democratic party issues such as civil rights and social welfare during Presidential campaigns when the incumbent president was a Republican. Our findings thus re-inforce our prior discussion that clean water was not a partisan issue.

\section{Editorial Campaigns and Political Preferences}

Was newspaper reporting on typhoid fever determined by editors' campaigns favoring the adoption of clean water technologies? If yes, we would expect more editorials on typhoid prior to the intervention. This "campaign" effect would therefore counteract our first hypothesis.

Figure 5 shows that only in Chicago was there a large number of editorials prior to the first intervention - the closing of the sewer outfalls of Lake Michigan. There were many editorials on the incompetence of the city for delays in sanitary reforms. The upsurge in editorials in New York City and in Boston prior to the sanitary reforms was associated with worries about typhoid during the Spanish-American War and the building of the Panama Canal. The editorials in Washington DC after the first intervention were largely articles about clean water interventions in other cities. The editorials in Boston after the second

\footnotetext{
${ }^{13}$ Our results were robust to the exclusion of the Spanish-American War, World War I, and the influenza pandemic.
} 
intervention focused on the dangers of typhoid on vacation. There were no editorials in Baltimore about typhoid.

A growing body of literature emphasizes media political slant in the left-right divide, whether on the demand or supply side, e.g, Larcinese, Puglisi, and Snyder (2011), Gentzkow and Shapiro (2010), and Mullainathan and Shleifer (2005). ${ }^{14}$ Clean water interventions were not part of the political divide in the United States in the early twentieth century. ${ }^{15}$ Demand for clean water and other sanitary reforms cut across party lines, with fear of contagion driving public support for public expenditures (Costa and Kahn 2015; Troesken 2004). For example, the initial 1897 vote for filtration in Philadelphia was favored by Republicans and opposed by Democrats. Initial bills for the expansion of New York City's water supply did not pass under either Democrat or Republican mayors. The main driver of spending was a previous outbreak (Cain and Rotella 2001), which a growing acceptance of the germ theory of disease attributed to contaminated water. Regression results in Appendix A show that the mayor's political party did not drive expenditures but that the previous year's typhoid death rate did. Because clean water infrastructure was a long-term project, media attention may have sped up expenditures. ${ }^{16}$

\section{Robustness: Diphtheria and the Media in New York City}

We test the robustness of our findings by comparing results for typhoid articles in New York City with diphtheria articles as a falsification test. Diphtheria, an upper respiratory tract infection, is spread through physical contact or breathing the aerosolized secretions of infected individuals and thus should not be affected by clean water interventions. In New York City, diphtheria death rates fell rapidly once antitoxin became widely available in 1895 (it was provided by the City). We would therefore not expect a positive effect of the interaction between typhoid death rates and typhoid interventions on the number of diphtheria articles. However, we would expect a more positive response to death rates after diphtheria antitoxin became widely available.

Tables 7 and 8 show that in New York City the effect of typhoid death rates on typhoid news reports is greater after the 1915 clean water intervention but the effect on diphtheria news reports is negative. Diphtheria death rates, however, have a greater effect on diphtheria news reports once antitoxin becomes widely available. In New York City, the standard deviation of typhoid deaths after 1911 was 0.096 and the standard deviation of diphtheria deaths was 0.563 after antitoxin became widely available. A half standard deviation increase in typhoid

\footnotetext{
${ }^{14}$ There is no evidence that the party in power affected the partisan composition of the press in this time period (Gentzkow, Petek, Shapiro, and Sinkinson 2015).

${ }^{15}$ The big political divisions in the US have been over the extension of slavery in the new territories in the $1850 \mathrm{~s}$, the creation of inflation by abandoning the gold standard and monetizing silver in the 1890 s, and civil rights for African-Americans beginning in the 1930s. The divisions in the 1890s were largely between agrarian and urban interests and were within parties (Poole and Rosenthal 1993).

${ }^{16}$ Where politics most likely played a roled was in the structure of expenditures, including capital and labor tradeoffs, the awarding of contracts, and the administration of waterworks. The original bill for the creation of the Sanitary District of Chicago (approved in 1889 by the state legislature) included plans for the construction of a 28 mile Sanitary and Shipping Canal and the management of the waterworks. The bill was originally supported by the Citizens' Association and Republicans but was reformulated to appeal to city and downstate Democrats by widening the canal to allow for shipping (which also meant that the costs would largely fall to the state and national governments) and by leaving control of the highly profitable waterworks to city aldermen who used the surplus for their favorite projects (Platt 2005: 371).
} 
deaths led to an increase of $0.25(=0.048 \times 5.124)$ in the number of articles with an additional increase of 0.704 articles $(=0.048 \times 14.670)$ after the intervention. This last increase was one of $40 \%$. Note that the interaction effects of typhoid interventions with the typhoid death rate had a statistically significant negative effect on the total number of diphtheria articles. However, after 1895 , when diphtheria antitoxin became widely available in the New York City, a half standard deviation increase in the diphtheria death rate increased the number of diphtheria news reports by an additional $0.03(=0.282 \times 0.100)$, a $2 \%$ increase.

Our hand-collected data for New York City for 1900-1930 allows us to investigate the use of alternative dependent variables. These included dummies equal to one if the article was largely about typhoid at the time of writing, if the article was largely about local typhoid at the time of writing, and if the article was a high profile one (either on the title page, more than half a page in length, or with typhoid in the title). In all cases the interaction between the second intervention and the death rate was statistically significant (results not shown).

\section{Conclusion}

At a time before television, radio and the internet, newspapers played a central role in disseminating information and thus guiding their readers' choices and viewpoints. Although we do not have direct evidence on newspapers' ability to affect behavior and opinions, case studies suggest that recent media campaigns have reduced smoking, cocaine use by teenagers, HIV infection rates, and deaths from Reyes syndrome (Hornik 2008). Several different research designs have yielded clear evidence of the impact of media on behavior. Outcome variables have included voter turnout (Gentzkow, Shapiro, and Sinkinson 2011), voting outcomes (DellaVigna and Kaplan 2007; cf., Gentzkow, Shapiro, and Sinkinson 2011), and disaster relief contributions (Eisensee and Stromberg 2007). Despite these limitations, the availability of weekly typhoid death and case reports permits us to test how major urban newspapers responded to emerging public health trends during a key time in urban history.

Between 1880 and 1940, today's developed countries experienced a major urban public health transition (see Haines 2001 on the US, Kestzenbaum and Rosenthal 2011 on France, and Brown 2000 on the UK and Germany). How does the media cover the emerging story during a time of rapid progress? We found that news reports were positively associated with typhoid death rates but that the size of the effect grew after cities cleaned up their water supplies. In addition, we also found that news coverage was more responsive to bad news (i.e., unexpected increases in death rates) than to good news (unexpected decreases in death rates).

We have documented the remarkable convergence in death rates from typhoid across city wards between 1900 and 1930 in prior work (Costa and Kahn 2015). This convergence was achieved through clean water interventions financed through the municipal bond market and backed up by property tax revenue. The poor and non-whites disportionately benefited. Clean water interventions and hence convergence may not have been possible if the media had not been able to galvanize elite opinion into tackling the big public health issue of the 
day. The media may have thus have served as co-ordination device (Strömberg 2015b) for different political interests and social classes.

\section{Acknowledgments}

We thank Hoyt Bleakley, Ed Glaeser, Rick Hornbeck, Luigi Zingales and seminar participants at the 2015 AEA Meetings, the 2015 NBER Summer Institute, Stanford University, UCLA, University of Chicago's November 2015 Media Economics Conference, Washington University, St. Louis and Yale University for helpful comments. Dora Costa gratefully acknowledges the support of NIH grant P01 AG10120 and the use of facilities and resources at the California Center for Population Research, UCLA, which is supported in part by NICDH grant R24HD041022.

\section{References}

1. Alsan, Marcella, Goldin, Claudia. Unpublished MS: Harvard University; 2015. Watersheds in Infant Mortality: The Role of Effective Water and Sewerage Infrastructure, 1880-1915. http:// scholar.harvard.edu/goldin/publications

2. Anderson, Simon P., McLaren, John. Media mergers and media bias with rational consumers. Journal of the European Economic Association. 2012; 10(4):831-859.

3. Baron, David P. Persistent media bias. Journal of Public Economics. 2006; 90(1-2):1036.

4. Beach, Brian, Ferrie, Joseph, Saavedra, Martin, Troesken, Werner. Typhoid Fever, Water Quality, and Human Capital Formation. The Journal of Economic History. 2016; 76(1):41-76.

5. Besley, Timothy, Burgess, Robin. The Political Economy of Government Responsiveness: Evidence from India. The Quarterly Journal of Economics. 2002; 117(4):1415-1451.

6. Besley, Timothy, Prat, Andrea. Handcuffs for the grabbing hand?: media capture and government accountability. American Economic Review. 2006; 96(3):720-736.

7. Brown, John C. Wer bezahlte die hygienische Stadt? Finanzielle Aspekte der sanitaären Reformen in England, USA, und Deutschland um 1910 [Who Paid for the Sanitary City? Issues and Evidence Ca. 1910]. Vögele, Jörg, Woelk, Wolfgang, editors. Stadt, Krankheit, und Tod. Berlin: Duncker and Humblot; 2000b. p. 237-257.

8. Cain, Louis, Rotella, Elyce. Death and Spending: Urban Mortality and Municipal Expenditure on Sanitation. Annales de Dé;mographie Historique. 2001:139-154. 2001/1 n 101.

9. Carroll, Christopher. Macroeconomic Expectations of Households and Professional Forecasters. The Quarterly Journal of Economics. 2003; 118(1):269-298.

10. Costa, Dora L., Kahn, Matthew E. Declining Mortality Inequality within Cities during the Health Transition. American Economic Review, Papers and Proceedings. 2015; 105(5):564-569.

11. Cutler, David, Miller, Grant. The Role of Public Health Improvements in Health Advances: The Twentieth-Century United States. Demography. 2005; 42(1):1-22. [PubMed: 15782893]

12. Cutler, David, Miller, Grant. Water, Water Everywhere: Municipal Finance and Water Supply in American Cities. In: Glaeser, Goldin, editors. Corruption and Reform: Lessons from America's Economic History. 2006.

13. Deaton, Angus. The Great Escape: Health, Wealth, and the Origins of Inequality. Princeton, NJ: Princeton University Press; 2013.

14. Dyck, Alexander, Moss, David, Zingales, Luigi. Media versus Special Interests. Journal of Law and Economics. 2013; 56(3):521-553.

15. DellaVigna, Stefano, Kaplan, Ethan. The Fox News Effect: Media Bias and Voting. Quarterly Journal of Economics. 2007; 122(3):1187-1234.

16. Eisensee, Thomas, Strömberg, David. News droughts, news floods, and US disaster relief. The Quarterly Journal of Economics. 2007; 122(2):693-728.

17. Emerson, Haven, Hughes, Harriet E. Population, Births, Notifiable Diseases, and Deaths, Assembled for New York City, NY. 1941:1866-1938.

18. Frost, Karen, Frank, Erica, Maibach, Edward. Relative Risk in the News Media: A Quantification of Misrepresentation. American Journal of Public Health. 1997; 87(5):842-845. [PubMed: 9184517] 
19. Gentzkow, Matthew, Glaeser, Edward, Goldin, Claudia. The Rise of the Fourth Estate: How Newspapers Became Informative and Why It Mattered. In: Glaeser, Goldin, editors. Corruption and Reform: Lessons from America's Economic History. 2006.

20. Gentzkow, Matthew, Petek, Nathan, Shapiro, Jesse M., Sinkinson, Michael. Do Newspapers Serve the State? Incumbent Party Influence on the US Press, 1869-1928. Journal of the European Economic Association. 2015; 31(1)

21. Gentzkow, Matthew, Shapiro, Jesse M. Competition and Truth in the Market for News. Journal of Economic Perspectives. 2008; 22(2):133-154.

22. Gentzkow, Matthew, Shapiro, Jesse M. What Drives Media Slant? Evidence from U.S. Daily Newspapers. Econometrica. 2010; 78(1):35-71.

23. Gentzkow, Matthew, Shapiro, Jesse M., Sinkinson, Michael. The Effect of Newspaper Entry and Exit on Electoral Politics. American Economic Review. 2011; 101(7):2980-3018.

24. Gentzkow, Matthew, Shapiro, Jesse M., Sinkinson, Michael. United States Newspaper Panel, 1869-2004. ICPSR30261-v6. Ann Arbor, MI: Inter-university Consortium for Political and Social Research [distributor]; 2014. http://doi.org/10.3886/ICPSR30261.v6 [2014-12-10]

25. Gernon, Maud, Hamilton, Alice, House, Hull. An inquiry into the causes of the recent epidemic of typhoid fever in Chicago, made by residents of Hull House : house-to-house investigation by Maud Gernon and Gertrude Howe ; Bacteriological inquiry as to the relation of the common housefly to the spread of the epidemic, Dr. Alice Hamilton. City Homes Association of Chicago; 1903.

26. Haines, Michael. R The Urban Mortality Transition in the United States, 1800 to 1940. Annales De Demographie Historique. 2001; 1:33-64.

27. Hamilton, James. All the News Thats Fit to Sell. Princeton University Press; 2004.

28. Hammond, Evelynn Maxine. Childhood's Deadly Scourge: The Campaign to Control Diphtheria in New York City, 1880-1930. Baltimore and London: Johns Hopkins University Press; 1999.

29. Hdornik, Robert C., editor. Public Health Communication: Evidence for Behavior Change. Mahwah, NJ: Lawrence Erlbaum Associaes, Inc.; 2002.

30. John, Jacob, Van Aart, Carola JC., Grassly, Nicholas C. The Burden of Typhoid and Paratyphoid in India: Systematic Review and Meta-analysis. PLOS Neglected Tropical Diseases. 2016; 10(4):e0004616. [PubMed: 27082958]

31. Kahneman, Daniel, Tversky, Amos. Prospect Theory: An Analysis of Decision Under Risk. Econometrica. 1979; 47(2):263-292.

32. Kesztenbaum, Lionel, Rosenthal, Jean-Laurent. The health cost of living in a city: The case of France at the end of the 19th century. Explorations in Economic History. 2011; 48(2):207-225.

33. Kunz, George Frederick. Catskill Aqueduct Celebration Publications. New York: The Mayor's Catskill Aqueduct Celebration Committee; 1917.

34. Larcinese, Valentino, Puglisi, Riccardo, Snyder, James M. Partisan Bias in Economic News: Evidence on the Agenda-Settng Behavior of U.S. Newspapers. Journal of Political Economy. 2011; 95(9-10):1178-1189.

35. Larreguy, Horacio A., Marshall, John, Snyder, James M, Jr. Revealing Malfeasance: How Local Media Facilitates Electoral Sanctions of Mayors in Mexico. NBER Working Paper No. 20697. 2014

36. Leitgöb, Heinz. Modeling Interactions in Count Data Regression Principles and Implementation in Stata. Slides. German Stata Users Group Meeting. 2014. http://www.stata.com/meeting/ germany14/abstracts/materials/de14_leitgoeb.pdf

37. Levine, Myron M. Typhoid Fever and Cholera Vaccines. In: de Quadros, Ciro A., editor. Vaccines: Preventing Disease and Protecting Health. Washington DC: Pan American Health Organization; 2003. p. 120-129.

38. Loewenstein, George, Mather, Jane. Dynamic Processes in Risk Perception. Journal of Risk and Uncertainty. 1990; 3(2):155-175.

39. Loud, Ralph W. The Metropolitan Sewerage Works. Journal of the Boston Society of Civil Engineers. 1923; 10(8):325-374.

40. Mankiw, N Gregory, Reis, Ricardo, Wolfers, Justin. Disagreement about Inflation Expectations. In: Gertler, Rogoff, editors. NBER Macroeconomics Annual 2003, Volume 18. 2004. 
41. McCarthy, Michael P. Memoirs of the American Philosophical Society Held at Philadelphia for Promoting Useful Knowledge. Vol. 179. Philadelphia: American Philosophical Society; 1987. Typhoid and the Politics of Public Health in Nineteenth-Century Philadelphia.

42. Mullainathan, Senhil, Shleifer, Andrei. The Market for News. American Economic Review. 2005; 95(4):1031-1053.

43. Platt, Harold L. Shock Cities: The Environmental Transformation and Reform of Manchester and Chicago. Chicago and London: The University of Chicago Press; 2005.

44. Poole, Keith T., Rosenthal, Howard. Spatial Realignment and the Mapping of Issues in American History: The Evidence from Roll Call Voting. In: Riker, William H., editor. Agenda Formation. Ann Arbor: University of Michigan Press; 1993.

45. Prat, Andrea, Strömberg, David. The Political Economy of Mass Media. In: Acemoglu, DaronArellano, Manuel, Dekel, Eddie, editors. Advances in Economics and Econometrics. Vol. 2. Cambridge: Cambridge University Press; 2013. p. 135-187.Applied Economics

46. Puglisi, Riccardo. Being the New York Times: The Political Behavior of a Newspaper. The BE Journal of Economic Analysis and Policy. 2011; 11(1) Contributions, Article 20. Available at: http://www.bepress.com/bejeap/vol11/iss1/art20.

47. Ram, N. An Independent Press and Anti-hunger Strategies: The Indian Experience. In: Drèze, Jean, Sen, Amartya, editors. The Political Economy of Hunger. Volume 1: Entitlement and Well-being. Oxford University Press; 1991. Published to Oxford Scholarship Online: January 2008

48. Strömberg, David. Media and Politics. The Annual Review of Economics. 2015a; 7:173-205.

49. Strömberg, David. Media Coverage and Political Accountability: Theory and Evidence. In: Anderson, SimonStrmberg, David, Waldfogel, Joel, editors. preparation for Handbook of Media Economics. 2015b.

50. Soroka, Stuart N. Good News and Bad news: Asymmetric Responses to Economic Information. The Journal of Politics. 2006; 68(2):372-385.

51. Troesken, Werner. Typhoid Rates and the Public Acquisition of Private Waterworks, 1880-1920. Journal of Economic History. 1999; 59(4):927-948.

52. Troesken, Werner. Water, Race and Disease. Cambridge, MA: MIT Press; 2004.

53. Wain, John, Hendriksen, Rene S., Mikoleit, Matthew L., Keddy, Karen H., Ochiai, R. Leon Typhoid Fever. Lancet. 2015 Mar 21.385:1136-1145. [PubMed: 25458731]

54. Waldfogel, Joel. The median voter and the median consumer: Local private goods and population composition. Journal of Urban Economics. 2008; 63(2):567-582.

\section{Appendix A: Determinants of City Capital Expenditures on Water}

We regressed the logarithm of inflation adjusted city capital expenditures on water (lwater) on a dummy equal to one if the mayor was a Democrat (D), the previous two years' death rates per 100,000 from typhoid $\left(d_{i-1}, d_{i-2}\right)$, the logarithm of city population (p), city (C) fixed effects, and fixed effects for every 3 years $(Y)$. That is, we estimate using OLS,

$$
\text { lwater }_{i}=\beta_{0}+\beta_{1} D_{i}+\beta_{2} d_{i-1}+\beta_{3} d_{i-2}+\beta_{4} \log \left(p_{i}\right)+\beta_{5} C_{i}+\beta_{6} Y_{i}+u_{i}
$$

where $u_{i}$ is the error term, $\mathrm{C}$ and $\mathrm{Y}$ are vectors of fixed effecfs, and we cluster on the city using the wild cluster bootstrap-t procedure for small clusters, as described by Cameron, Gelbach, and Miller (2008). We used Cain and Rotella (2001)'s 1899-1929 data for our six cities (Baltimore, Boston, Chicago, New York City, Philadelphia, and Washington DC), augmenting the data with information on the mayor's political party obtained from http:// www.worldstatesmen.org/US_Mayors.html. Annual data are not available for all cities, hence the use of fixed effects for every 3 years. 
Table 9 shows that the only statistically significant predictor of current capital expenditures on water was the prior year's death rate, suggesting that cities sped up expenditures in response to increases in the death rate. The impact of the mayor's party is statistically insignificant but the magnitude suggests that under a Democratic mayor expenditures rose $23 \%$. When we exclude Baltimore, the magnitude of the coefficient falls to imply only an $8 \%$ increase.

Table 9

Predictors of City Capital Expenditures on Water, Six Cities

\begin{tabular}{lll}
\hline & & $\begin{array}{l}\text { excluding } \\
\text { Baltimore }\end{array}$ \\
\hline Dummy=1 if Democrat & 0.226 & 0.076 \\
& $(0.304)$ & $(0.333)$ \\
Typhoid death rate one year ago & $0.031^{\neq}$ & $0.035^{f}$ \\
& $(0.008)$ & $(0.008)$ \\
Typhoid death rate two years ago & -0.002 & -0.005 \\
& $(0.010)$ & $(0.009)$ \\
Logarithm of city population & -0.7378 & -0.349 \\
Constant & $(1.066)$ & $(1.297)$ \\
\multirow{2}{*}{$R^{2}$} & 20.197 & 14.899 \\
Observations & $(14.114)$ & $(16.952)$ \\
\hline
\end{tabular}

The dependent variable is the logarithm of inflation adjusted capital expenditures on water. The regressions include city and three year fixed effects. Standard errors, clustered on the city using the wild cluster bootstrap-t procedure (Cameron, Gelbach, and Miller 2008), are in parentheses. t $\mathrm{p}<0.01$

\section{Appendix B: Newspaper and Newspaper Market Characteristics}

Table B1

Number of Dailies and Total Circulation by City and Fraction of Circulation by Newspapers

\begin{tabular}{|c|c|c|c|c|}
\hline & $1890 \mathrm{~s}$ & $1900 \mathrm{~s}$ & $1910 \mathrm{~s}$ & $1920 \mathrm{~s}$ \\
\hline \multicolumn{5}{|c|}{ Mean Number of Dailies } \\
\hline Baltimore & 6.0 & 5.7 & 6 & 7 \\
\hline Boston & 9.5 & 10.3 & 11.5 & 10 \\
\hline Chicago & 17.5 & 17.0 & 14.5 & 14 \\
\hline Manhattan & 28.5 & 33.3 & 31.5 & 34 \\
\hline Philadelphia & 16 & 12.7 & 11 & 8 \\
\hline Washington DC & 4 & 3.3 & 6 & 6 \\
\hline \multicolumn{5}{|l|}{ Total Circulation } \\
\hline Baltimore & 122,161 & 231,242 & 321,569 & 499,201 \\
\hline Boston & 591,010 & 798,438 & $1,385,030$ & $1,438,624$ \\
\hline Chicago & 72,674 & $1,200,937$ & $1,750,645$ & $2,005,540$ \\
\hline Manhattan & $1,725,248$ & $2,050,203$ & $3,146,567$ & $3,447,912$ \\
\hline Philadelphia & 725,518 & $1,074,513$ & $1,158,179$ & $1,407,737$ \\
\hline
\end{tabular}




\begin{tabular}{lllll}
\hline & $\mathbf{1 8 9 0 s}$ & $\mathbf{1 9 0 0 s}$ & $\mathbf{1 9 1 0 s}$ & $\mathbf{1 9 2 0 s}$ \\
\hline Washington DC & 78,618 & 114,706 & 143,710 & 301,143 \\
Percentage of Total Circulation & & & & \\
Baltimore Sun & 40.9 & 29.2 & 40.4 & 55.0 \\
Boston Globe & 29.7 & 23.9 & 15.5 & 19.4 \\
Chicago Tribune & 10.2 & 8.5 & 17.3 & 28.7 \\
New York Times & 2.3 & 5.0 & 8.3 & 9.5 \\
Philadelphia Inquirer & 11.4 & 15.1 & 15.9 & 16.5 \\
Washington Post & 31.4 & 26.4 & 23.5 & 19.9 \\
\hline
\end{tabular}

Calculated from Gentzkow, Shapiro, and Sinkinson (2014). The percentage of circulation for the Sun and the Globe include both the morning and evening paper.

\section{Appendix C: Mechanized and Manual Searches}

Figure C1 compares our mechanized searches of The New York Times for typhoid fever with manual searches for 1900-1932. Except for some learning by doing by data inputters in the early manual searches, peaks and troughs in the percentage of articles mentioning typhoid coincide across the two samples. However, the mechanized searches for mentions of local typhoid fever yield a consistently greater percentage than the manual searches. The mechanized searches also capture deaths or illnesses of New Yorkers outside of the city.

Figure C1: Comparison of Manual and Mechanized Searches, The New York Times 19001932 


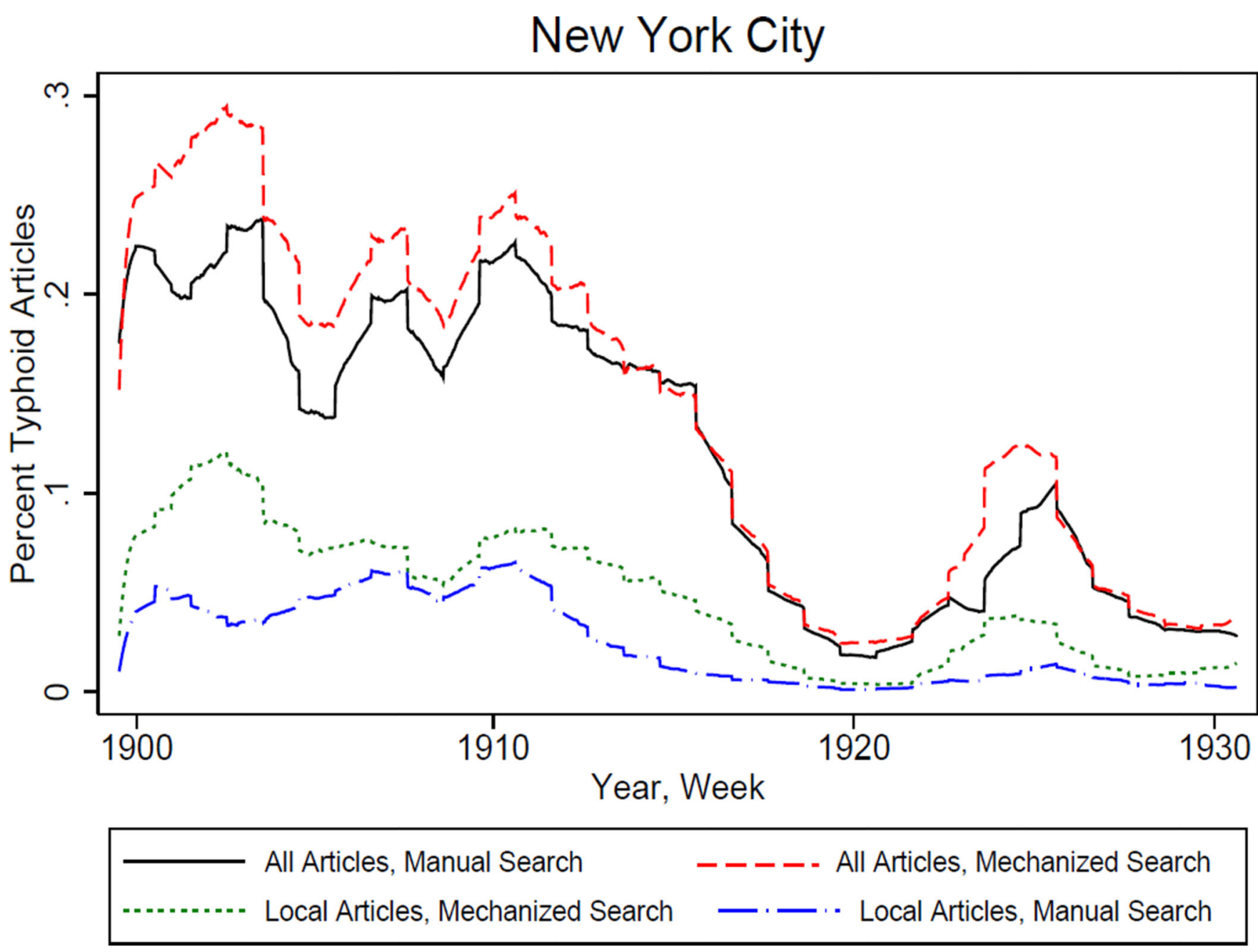

Source: The New York Times.

\section{Appendix D: Clean Water Interventions and Death Rates}

Table D1 shows that in all cities the first intervention was a statistically significant predictor of death rates, controlling for a year trend. Controlling for the effects of the first intervention, in all cities except for Washington DC the second intervention was a statistically significant predictor of death rates and the combined effect of both interventions was statistically significant in all cities except for Washington DC. The inclusion of lagged death rates in the specification also yielded statistically significant effects of the interventions (results not shown).

We also investigated whether the expansion of sewage systems in the Boston metropolitan area had any effects on typhoid rates in Boston. We included in our regression specification three dummy variables each equal to one, respectively, after 1892 (when the Charles River System was completed), after 1897 (when the Neponset Valley System was completed), and after 1904 (when the High Level System was completed). We did not find a statistically significant effect of any of the sewage dummies. We lost significance on the first clean water 
intervention (probably because after 1897 is too close to after 1898) but not on the second clean water intervention. Sewage construction continued after 1904. For example, high level sewers were constructed for Newton, Brighton, and Brookline in 1907, 1908, and 1909, respectively but these interventions are too close to the second clean water intervention (1908). The Mystic Sewer was built in 1912, 1913, and 1914 but we did not obtain any robust results for this intervention. 17

\section{Table D1}

OLS Regression of Effect of Clean Water Interventions on Typhoid Death Rates

\begin{tabular}{|c|c|c|c|c|c|c|}
\hline & NYC & Chicago & Baltimore & Boston & Philadelphia & DC \\
\hline 1st intervention & $\begin{array}{l}-0.116^{t} \\
(0.010)\end{array}$ & $\begin{array}{l}-0.158^{t} \\
(0.020)\end{array}$ & $\begin{array}{l}-0.080^{*} \\
(0.042)\end{array}$ & $\begin{array}{l}-0.075^{\dagger} \\
(0.030)\end{array}$ & $\begin{array}{l}-0.614^{\dagger} \\
(0.056)\end{array}$ & $\begin{array}{l}-0.257 \neq \\
(0.084)\end{array}$ \\
\hline 2nd intervention & $\begin{array}{l}-0.073{ }^{t} \\
(0.009)\end{array}$ & $\begin{array}{l}0.088^{*} \\
(0.021)\end{array}$ & $\begin{array}{l}-0.112 \neq \\
(0.039)\end{array}$ & $\begin{array}{l}-0.127 \% \\
(0.030)\end{array}$ & $\begin{array}{l}-0.197 * \\
(0.046)\end{array}$ & $\begin{array}{l}0.050 \\
(0.060)\end{array}$ \\
\hline Combined interventions & $\begin{array}{l}-0.189{ }^{*} \\
(0.013)\end{array}$ & $\begin{array}{l}-0.070^{\dagger} \\
(0.035)\end{array}$ & $\begin{array}{l}-0.192^{\dagger} \\
(0.043)\end{array}$ & $\begin{array}{l}-0.202^{\star} \\
(0.037)\end{array}$ & $\begin{array}{l}-0.811^{\ddagger} \\
(0.090)\end{array}$ & $\begin{array}{l}-0.207 \\
(0.132)\end{array}$ \\
\hline Observations & 2,548 & 1,538 & 1,387 & 1,588 & 904 & 1,558 \\
\hline$R^{2}$ & 0.517 & 0.503 & 0.391 & 0.396 & 0.476 & 0.428 \\
\hline
\end{tabular}

All regressions include a linear time trend and constant term. Robust standard errors in parentheses. $t_{\mathrm{p}}^{*}<0.01$

$t_{\mathrm{p}}<0.05$ $\mathrm{p}<0.1$

${ }^{17}$ For information on sewage systems see Alsan and Goldin (2015) and Loud (1923). 

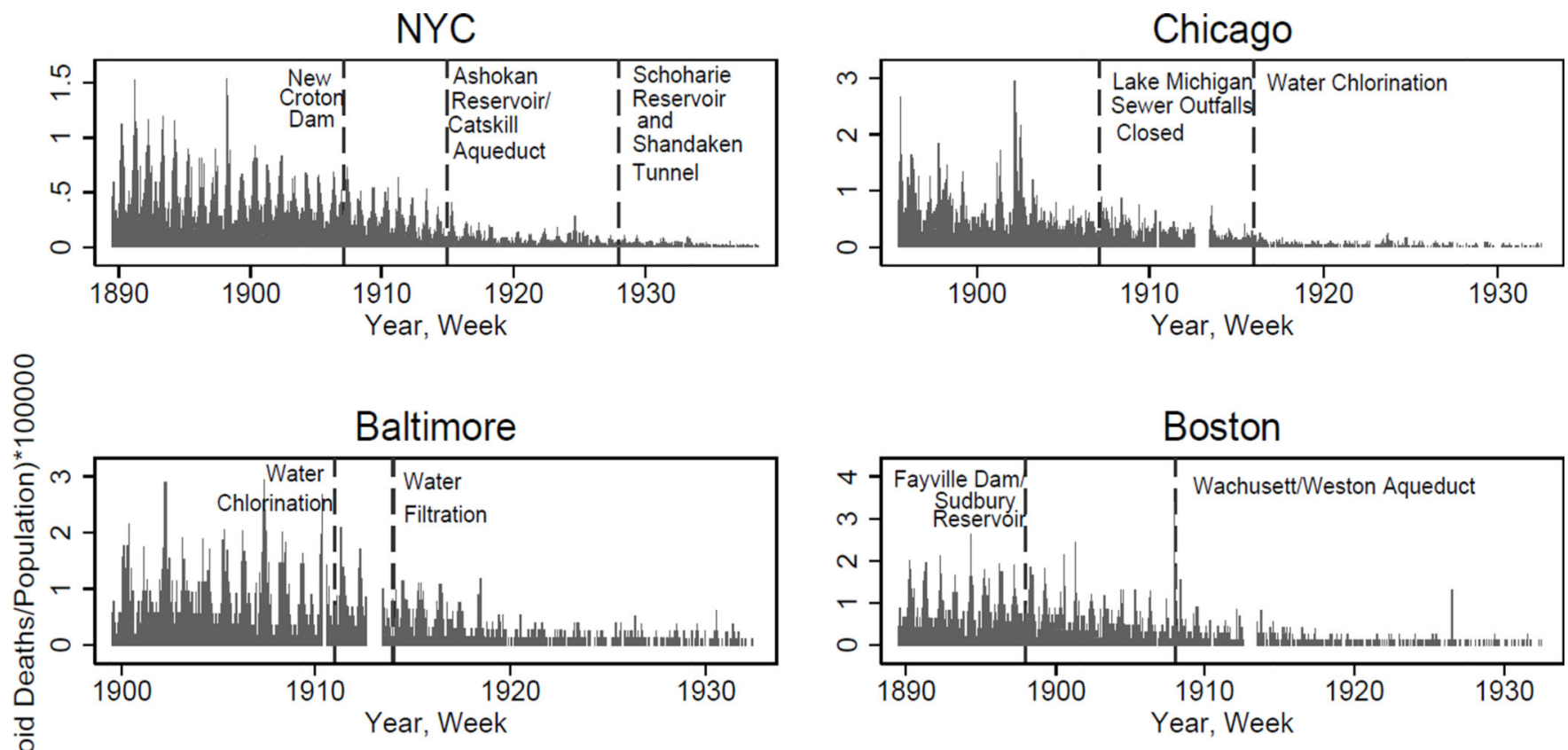

Philadelphia

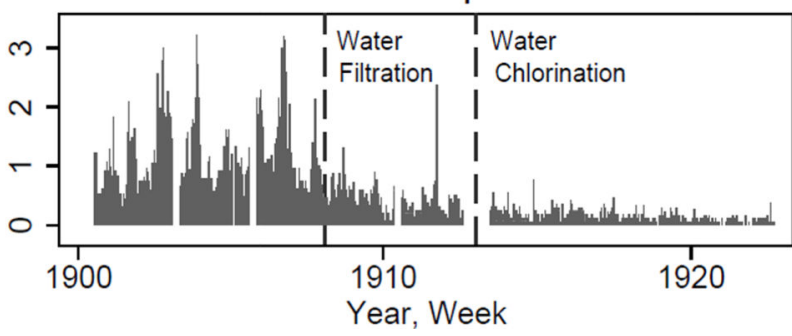

Figure 1.

Weekly Typhoid Death Rates by City

See the text for sources.

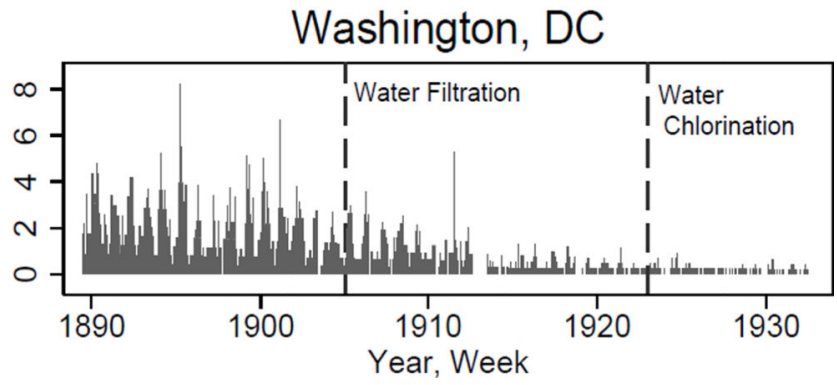



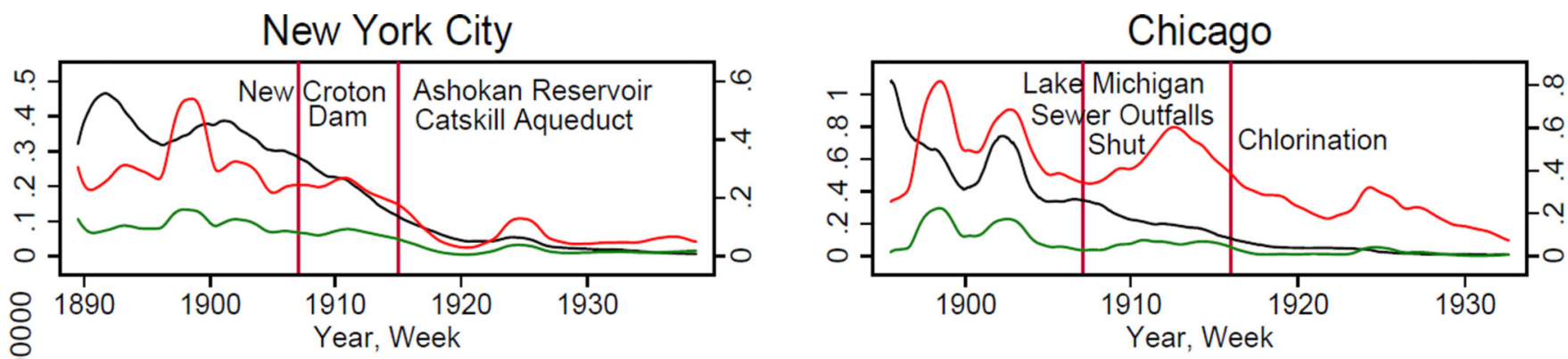

Baltimore
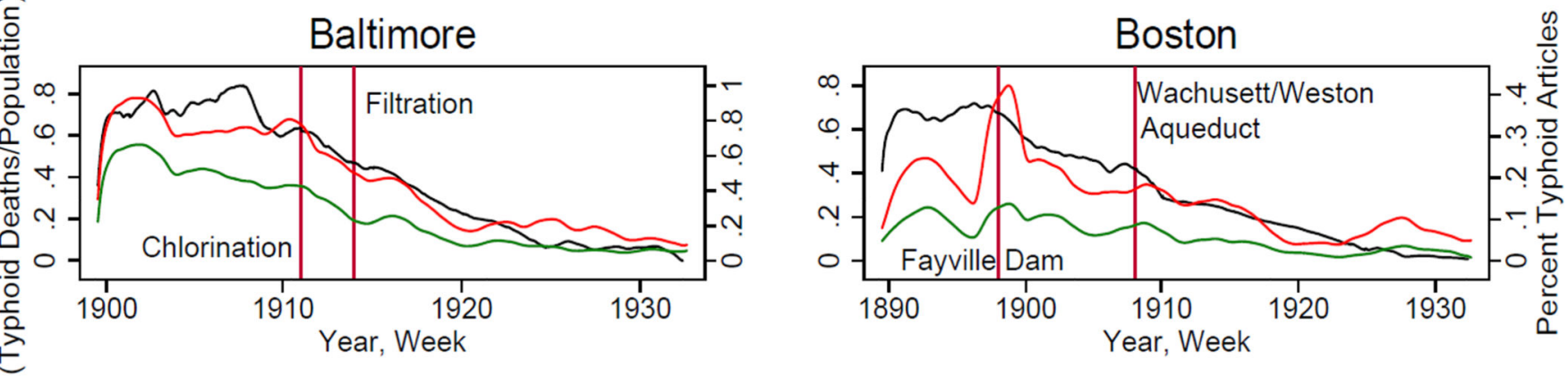

Philadelphia

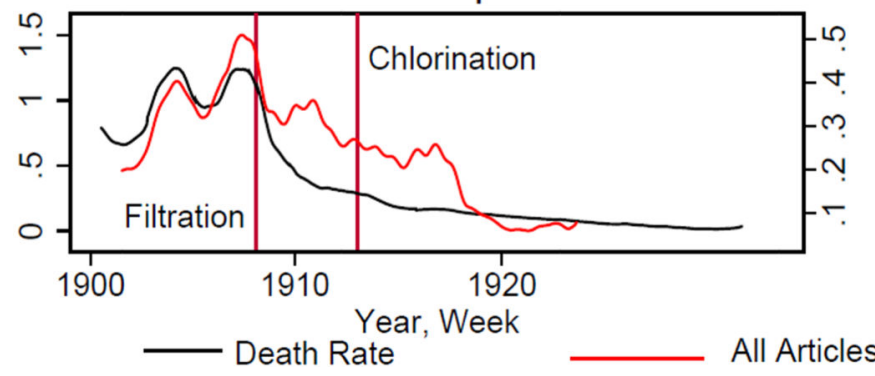

Washington, DC

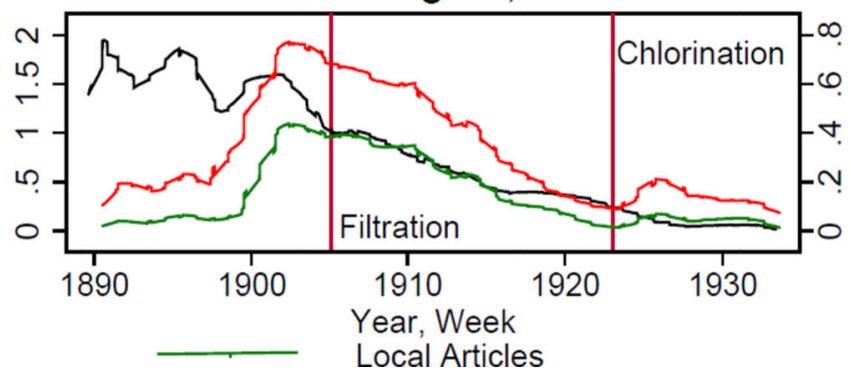

Figure 2.

Weekly Typhoid Death Rates and Percentage of Typhoid Articles by City

See the text for sources. Death rates and the percentage of articles were smoothed using a lowess estimator. 


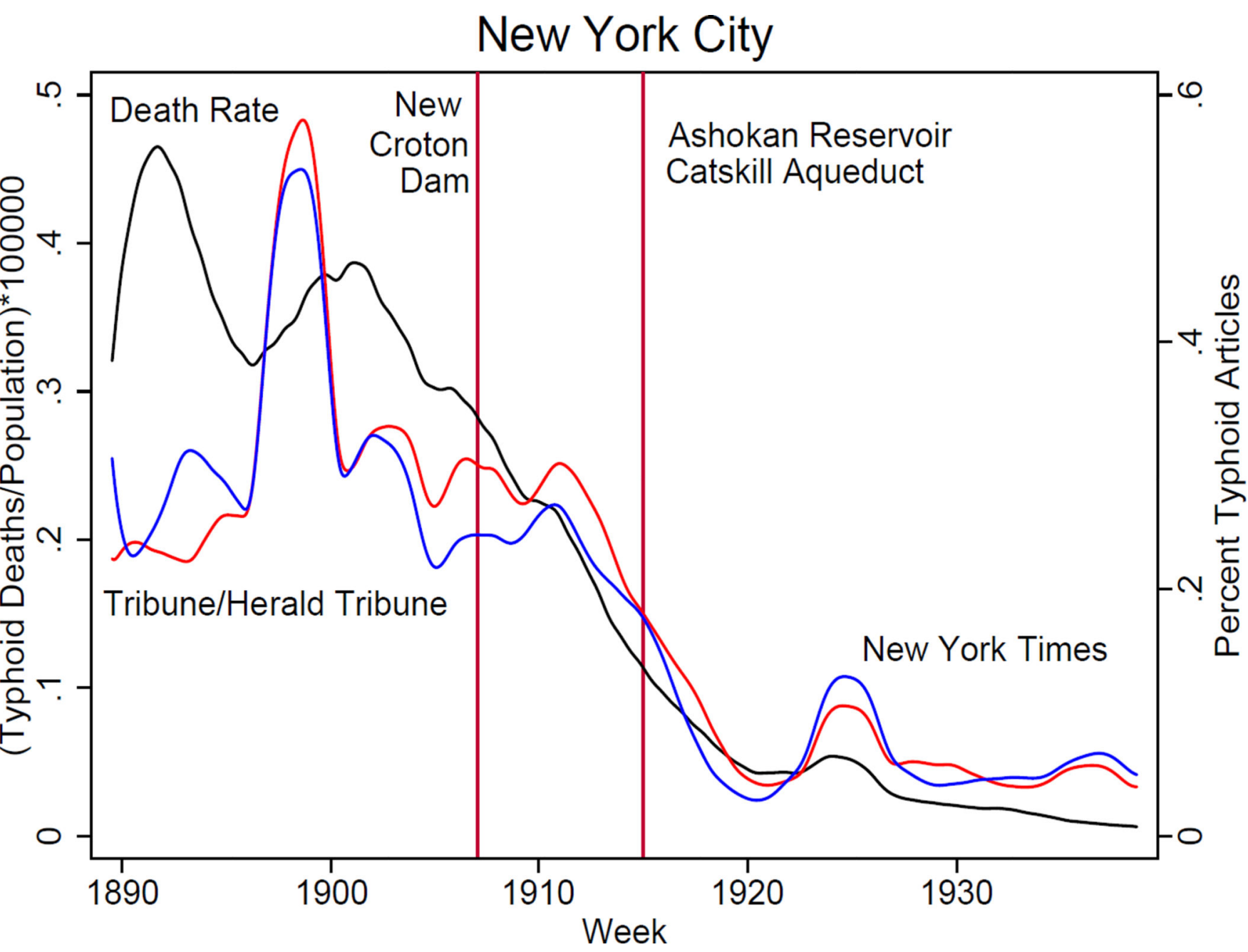

Figure 3.

New York City Weekly Typhoid Death Rates and Percentage of Typhoid Articles, New York Times and New York Tribune/Herald Tribune

See the text for sources. Death rates and the percentage of articles were smoothed using a lowess estimator. 

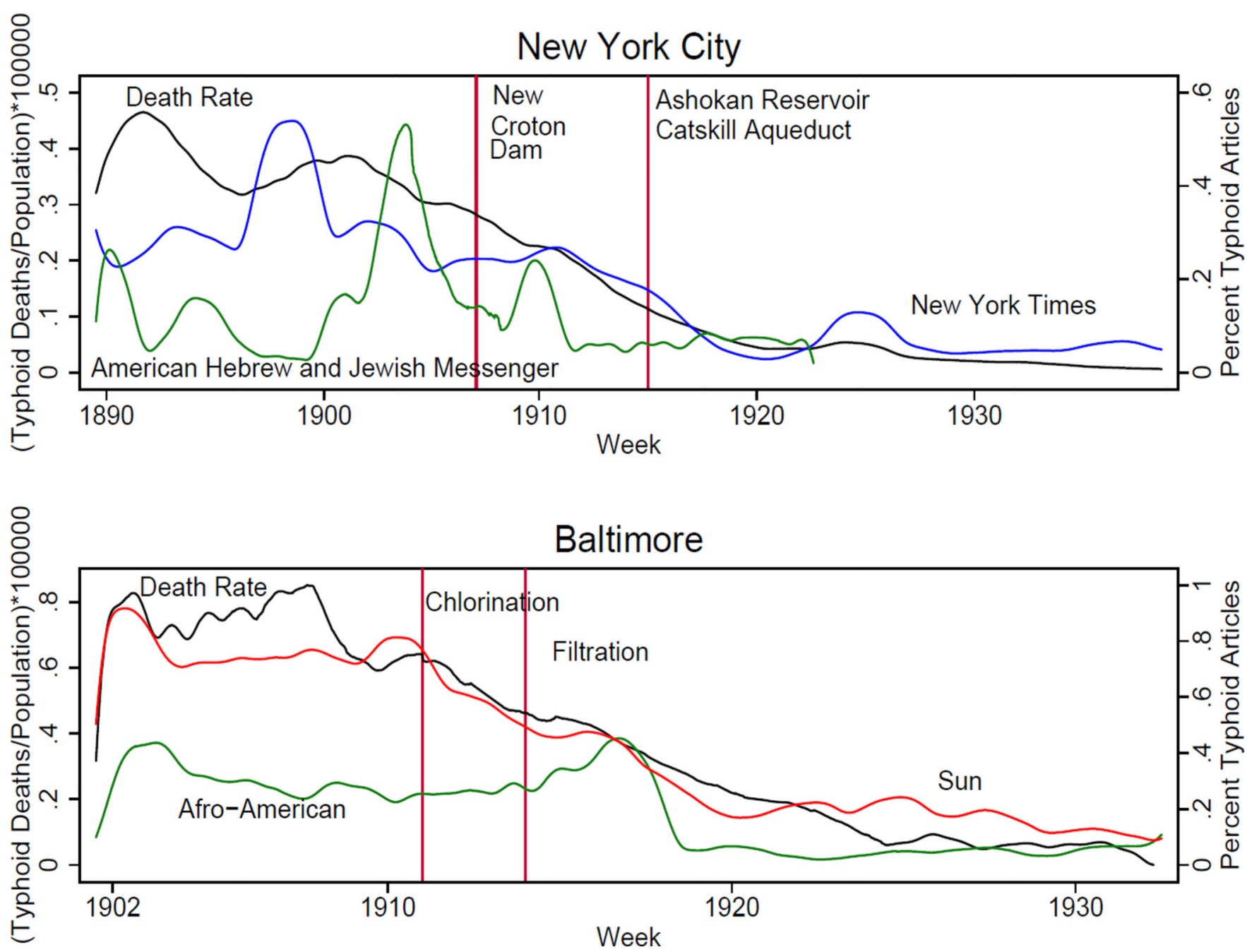

Figure 4.

Comparison of Leading and Minority Newspapers, New York City and Baltimore

See the text for sources. Death rates and the percentage of articles were smoothed using a lowess estimator. 

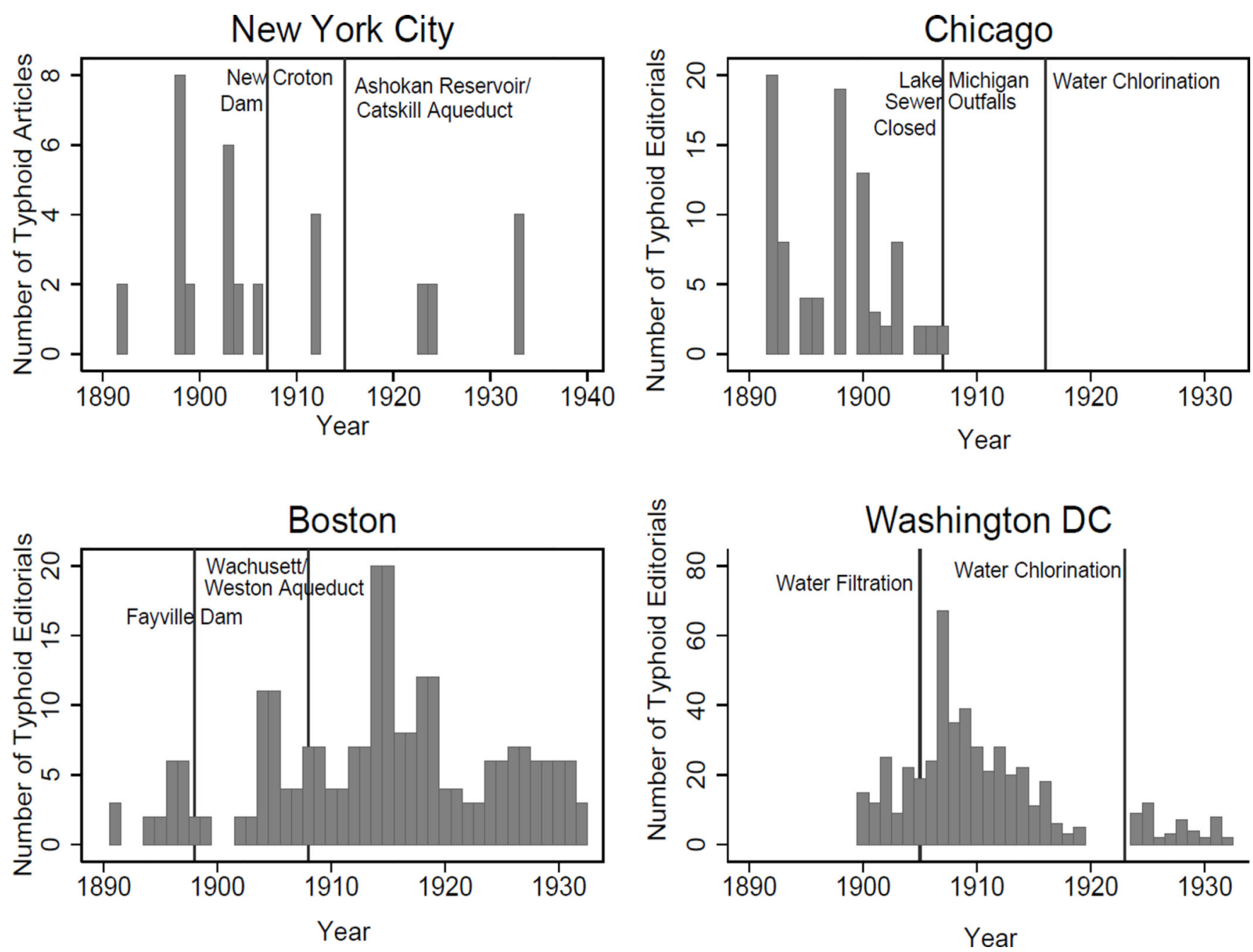

Figure 5.

Number of Typhoid Editorials by City

Editorials could not be identified for Philadelphia. There were no editorials in Baltimore. 


\section{Table 1}

\section{Clean Water Intervention Dates}

\begin{tabular}{lll}
\hline City & Intervention & Intervention \\
\hline Baltimore & 1911 & 1914 \\
& water chlorination & water filtration \\
\multirow{2}{*}{ Boston } & 1898 & 1908 \\
& Fayville Dam/Sudbury Reservoir & Wachusett/Weston Aqueduct \\
Chicago & 1907 & 1916 \\
& Lake Michigan sewer outfalls closed & water chlorination \\
New York City & 1907 & 1915 \\
& New Croton Dam & Ashokan Reservoir/Catskill Aqueduct \\
Philadelphia & 1908 & 1913 \\
& water filtration & water chlorination \\
Washington DC & 1905 & 1923 \\
& water filtration & water chlorination \\
\hline
\end{tabular}

Economica. Author manuscript; available in PMC 2018 July 01. 


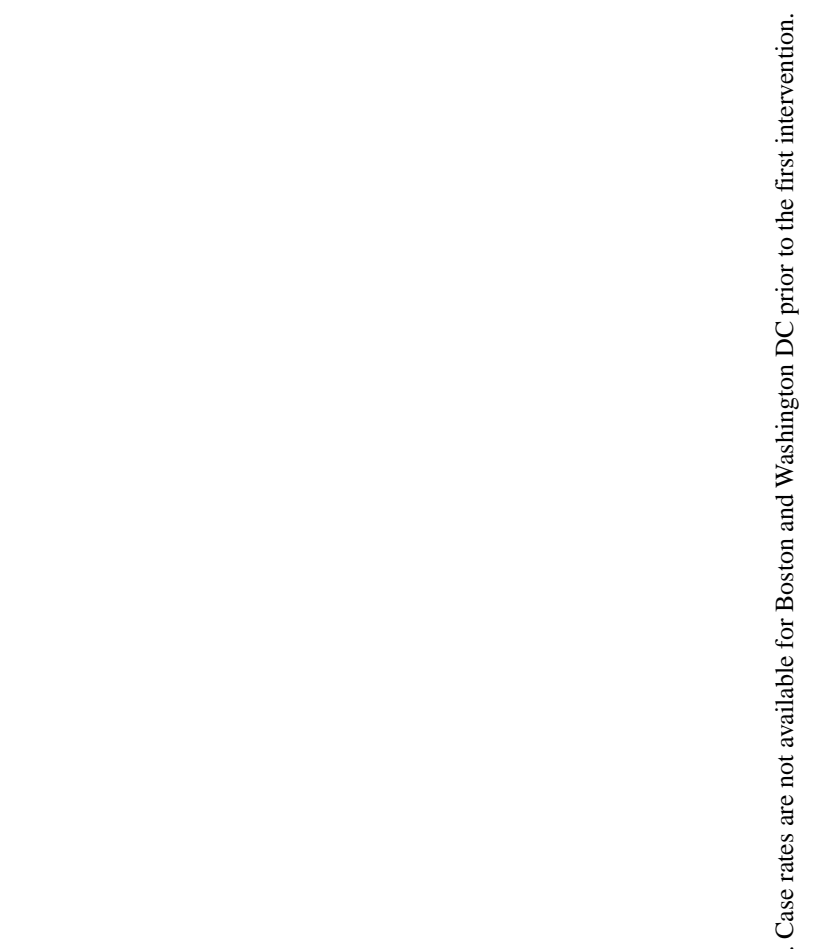

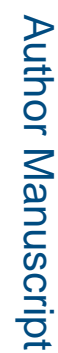

ำ
$\frac{0}{0}$
$\frac{1}{1}$

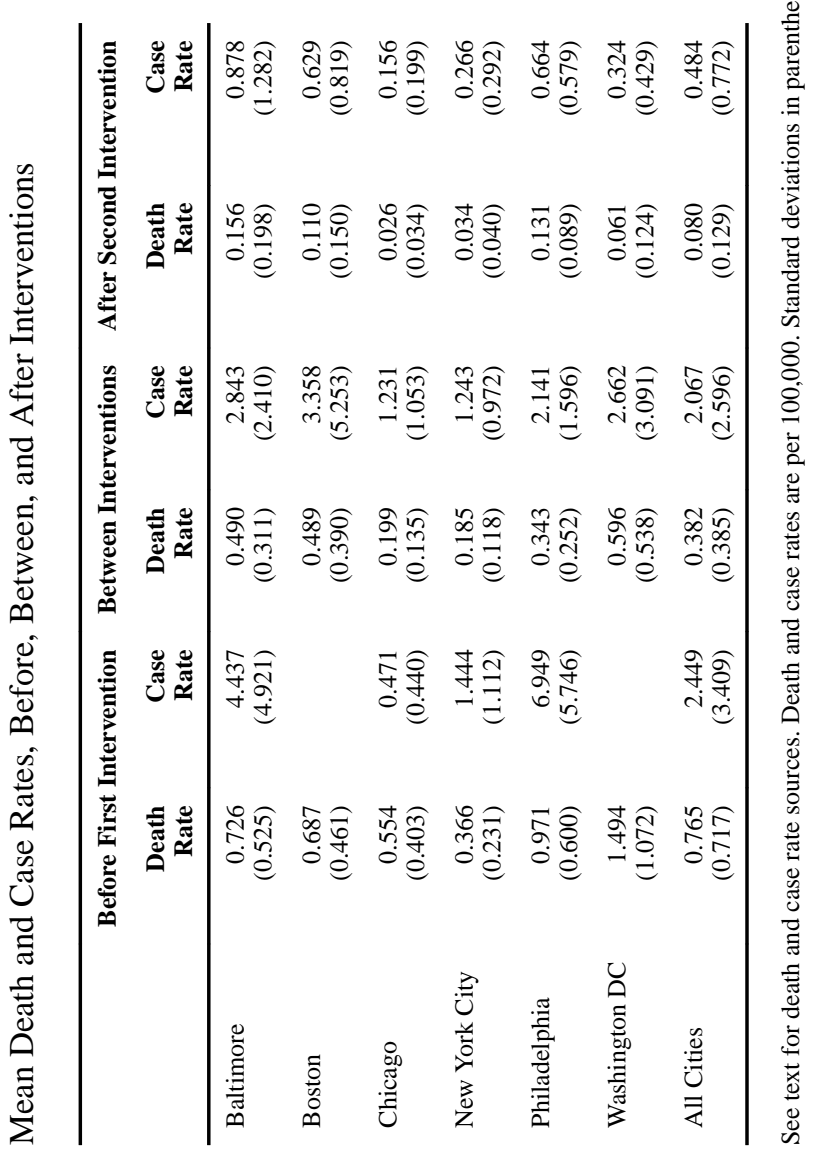

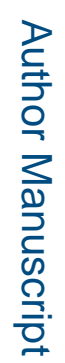




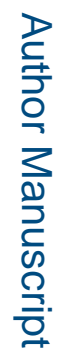

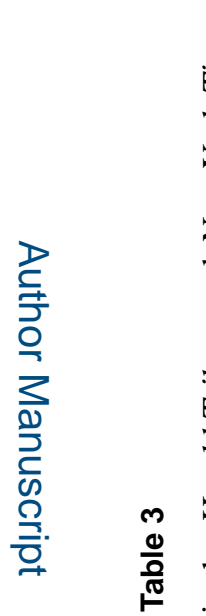

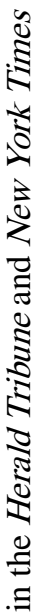

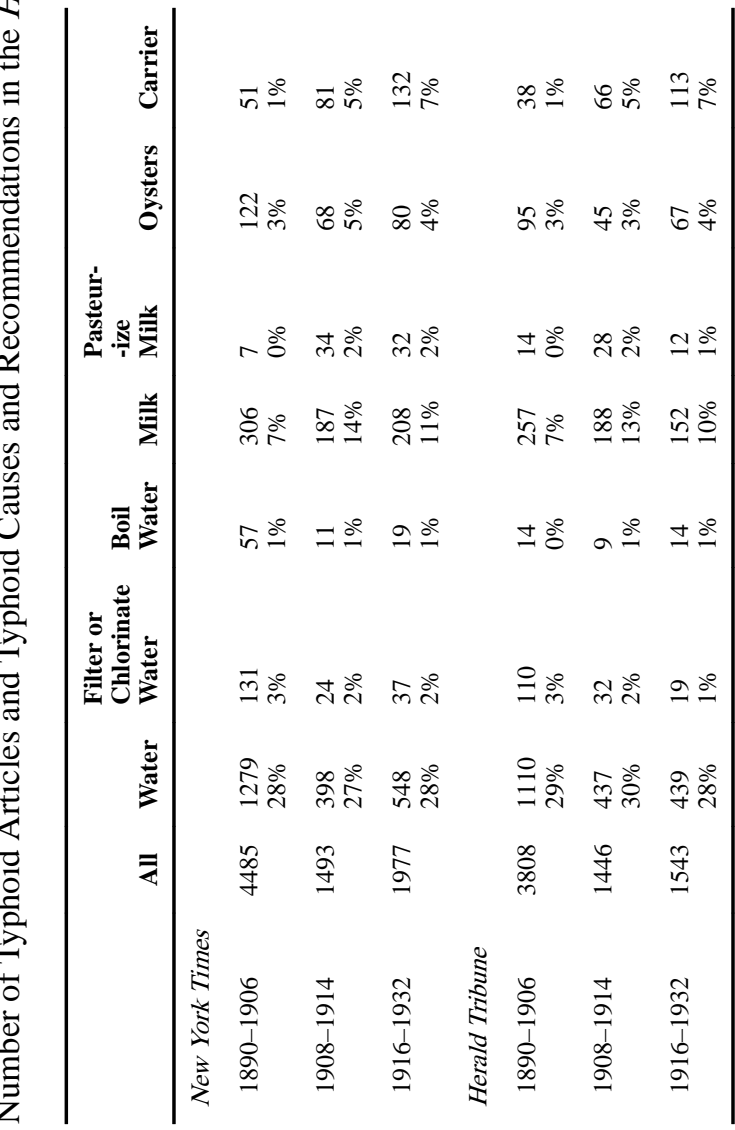

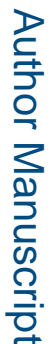

을

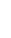

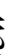



줌 


\section{을 \\ 골}

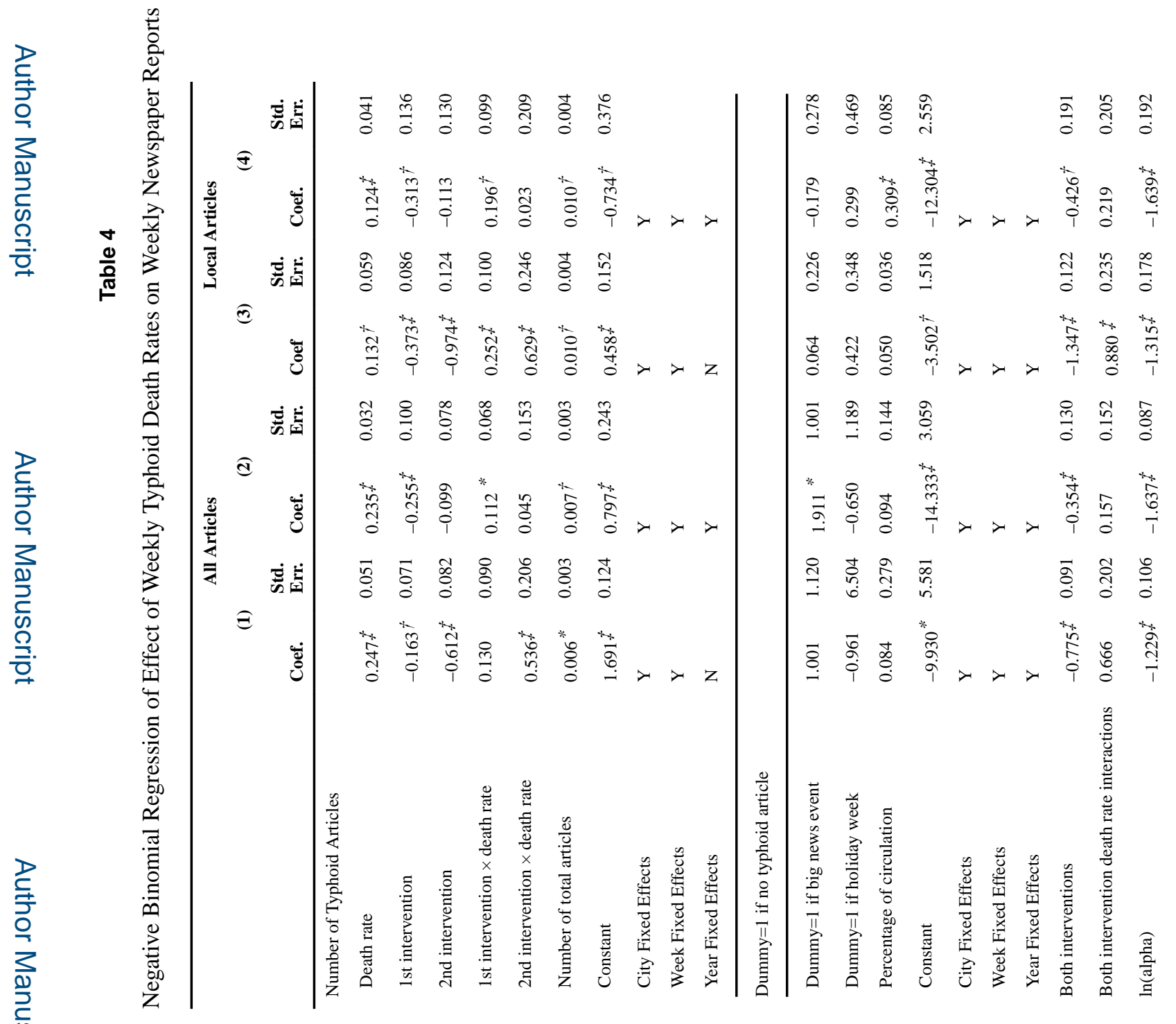

Economica. Author manuscript; available in PMC 2018 July 01. 


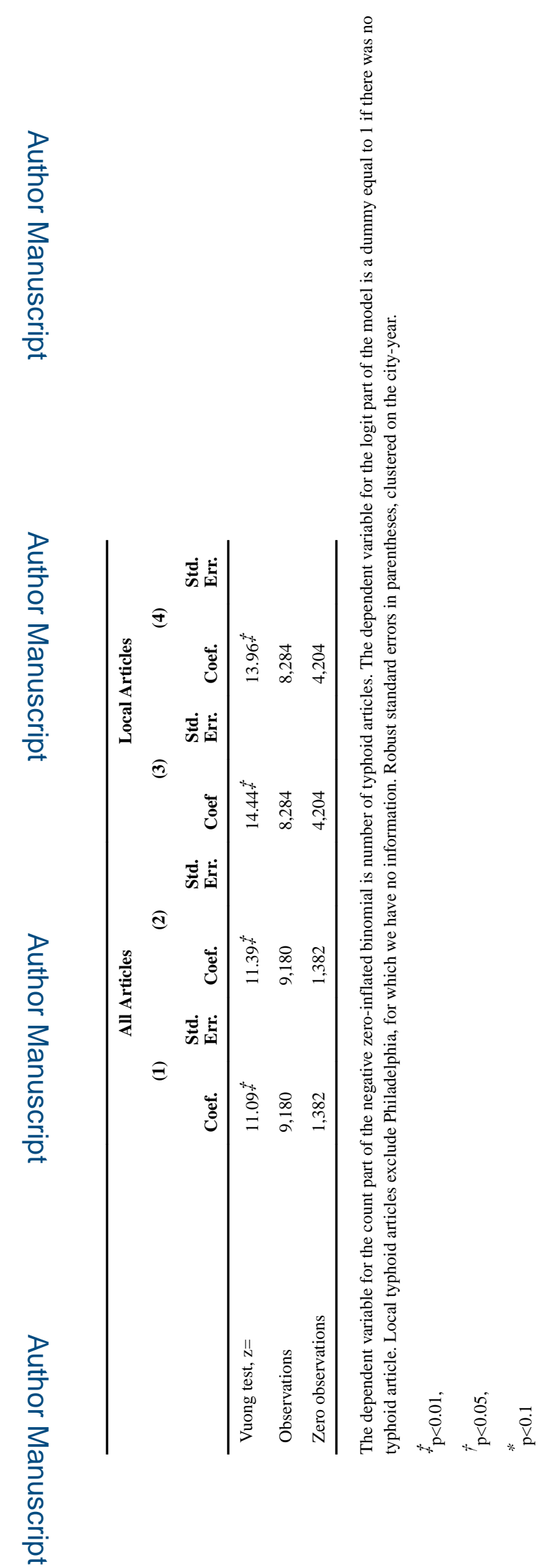

Economica. Author manuscript; available in PMC 2018 July 01. 


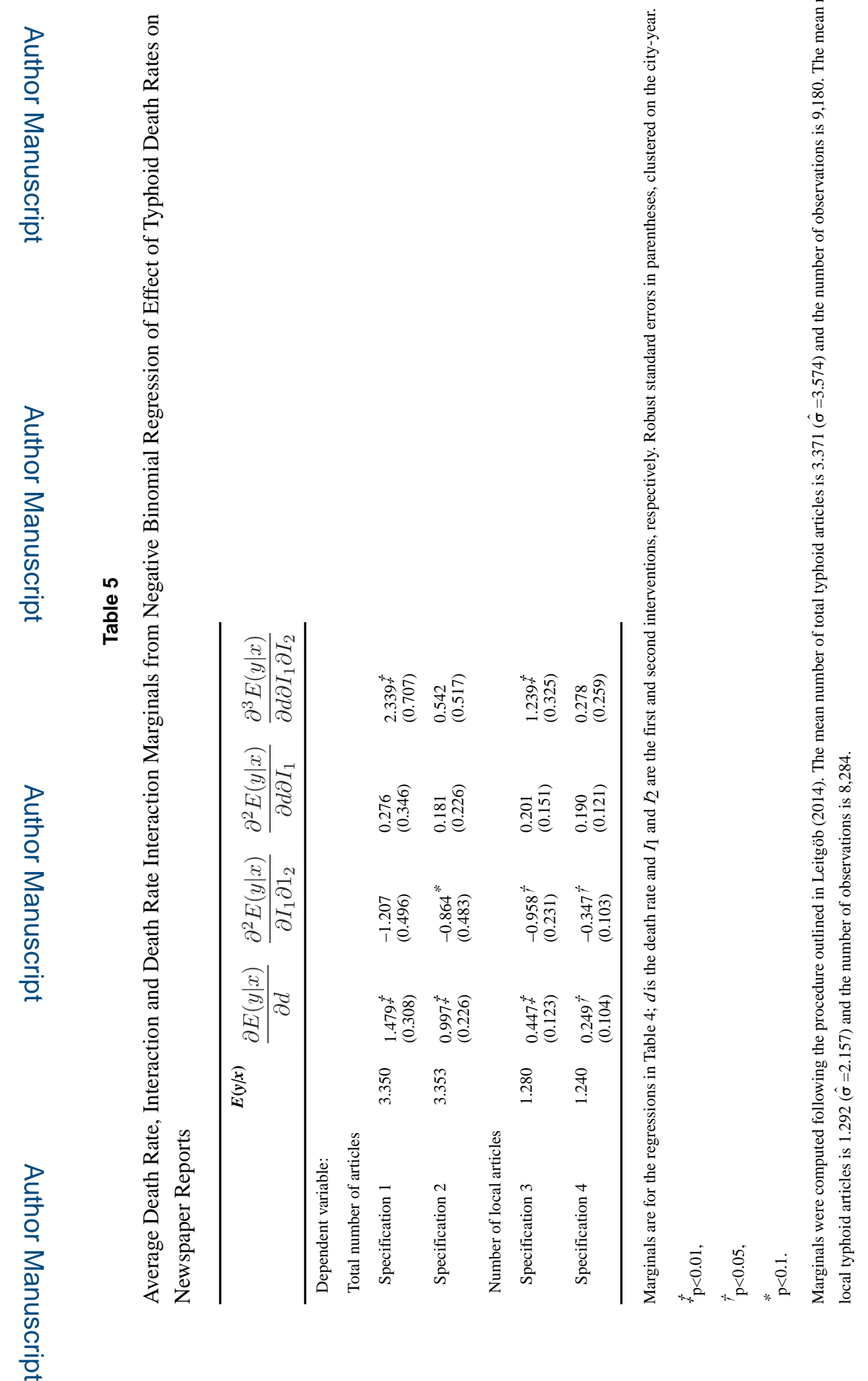

Economica. Author manuscript; available in PMC 2018 July 01. 
Table 6

Negative Binomial Regression and Marginals of Effect of Unexpected Negative News on Weekly Newspaper Reports

\begin{tabular}{|c|c|c|c|c|}
\hline & \multicolumn{2}{|c|}{ All Articles } & \multicolumn{2}{|c|}{ Local Articles } \\
\hline & Coef. & $\begin{array}{l}\text { Std. } \\
\text { Err. }\end{array}$ & Coef. & $\begin{array}{l}\text { Std. } \\
\text { Err. }\end{array}$ \\
\hline \multicolumn{5}{|l|}{ Number of Typhoid Articles } \\
\hline Death rate & $0.283 t^{t}$ & 0.031 & $0.246^{*}$ & 0.048 \\
\hline Dummy=1 if "bad" death news & $0.098^{*}$ & 0.028 & $0.174^{*}$ & 0.041 \\
\hline Number of total articles & $0.006^{\dagger}$ & 0.003 & 0.004 & 0.004 \\
\hline Constant & 0.176 & 0.180 & $-0.858^{* t}$ & 0.278 \\
\hline City Fixed Effects & $\mathrm{Y}$ & & $\mathrm{Y}$ & \\
\hline Year Fixed Effects & $\mathrm{Y}$ & & $\mathrm{Y}$ & \\
\hline \multicolumn{5}{|l|}{ Dummy $=1$ if no typhoid article } \\
\hline Dummy=1 if big news event & $3.032^{\dagger}$ & 1.426 & 0.073 & 0.285 \\
\hline Dummy $=1$ if holiday week & 0.424 & 1.064 & 0.477 & 0.567 \\
\hline Percentage of circulation & -0.119 & 0.122 & 0.081 & 0.072 \\
\hline Constant & $-18.646^{*}$ & 5.363 & $-18.842 \%$ & 1.927 \\
\hline Total effect of death rate and "bad" news & $0.381^{*}$ & 0.032 & $0.420^{*}$ & 0.051 \\
\hline $\ln ($ alpha $)$ & $-1.506^{t}$ & 0.083 & $-1.374^{*}$ & 0.167 \\
\hline Vuong test, $\mathrm{z}=$ & $11.17 *$ & & $13.71^{*}$ & \\
\hline Observations & 9,180 & & 8,284 & \\
\hline Zero observations & 1,382 & & 4,204 & \\
\hline$E(y / x)$ & 3.358 & & 1.319 & \\
\hline$\partial E(y \mid x$, no "bad" news $)$ & $0.949 F^{*}$ & 0.104 & $0.325^{*}$ & 0.063 \\
\hline$\partial d$ & & & & \\
\hline$\partial^{2} E(y \mid x$, "bad" news $)$ & $1.278^{t^{*}}$ & 0.107 & $0.554 *$ & 0.067 \\
\hline$\partial d$ & & & & \\
\hline
\end{tabular}

The dependent variable for the count part of the negative zero-inflated binomial is number of typhoid articles. The dependent variable for the logit part of the model is a dummy equal to 1 if there was no typhoid article. Robust standard errors in parentheses, clustered on the city-year. "Bad" news is a positive deviation from a rolling mean of death rates over the previous 2 years. The mean number of total typhoid articles is 3.371 ( $\hat{\sigma}$ $=3.574)$ and the mean number of local typhoid articles is $1.292(\hat{\sigma}=2.157)$.

$t_{\mathrm{p}}^{*}<0.01$,

$t_{\mathrm{p}}<0.05$,

p $<0.1$ 


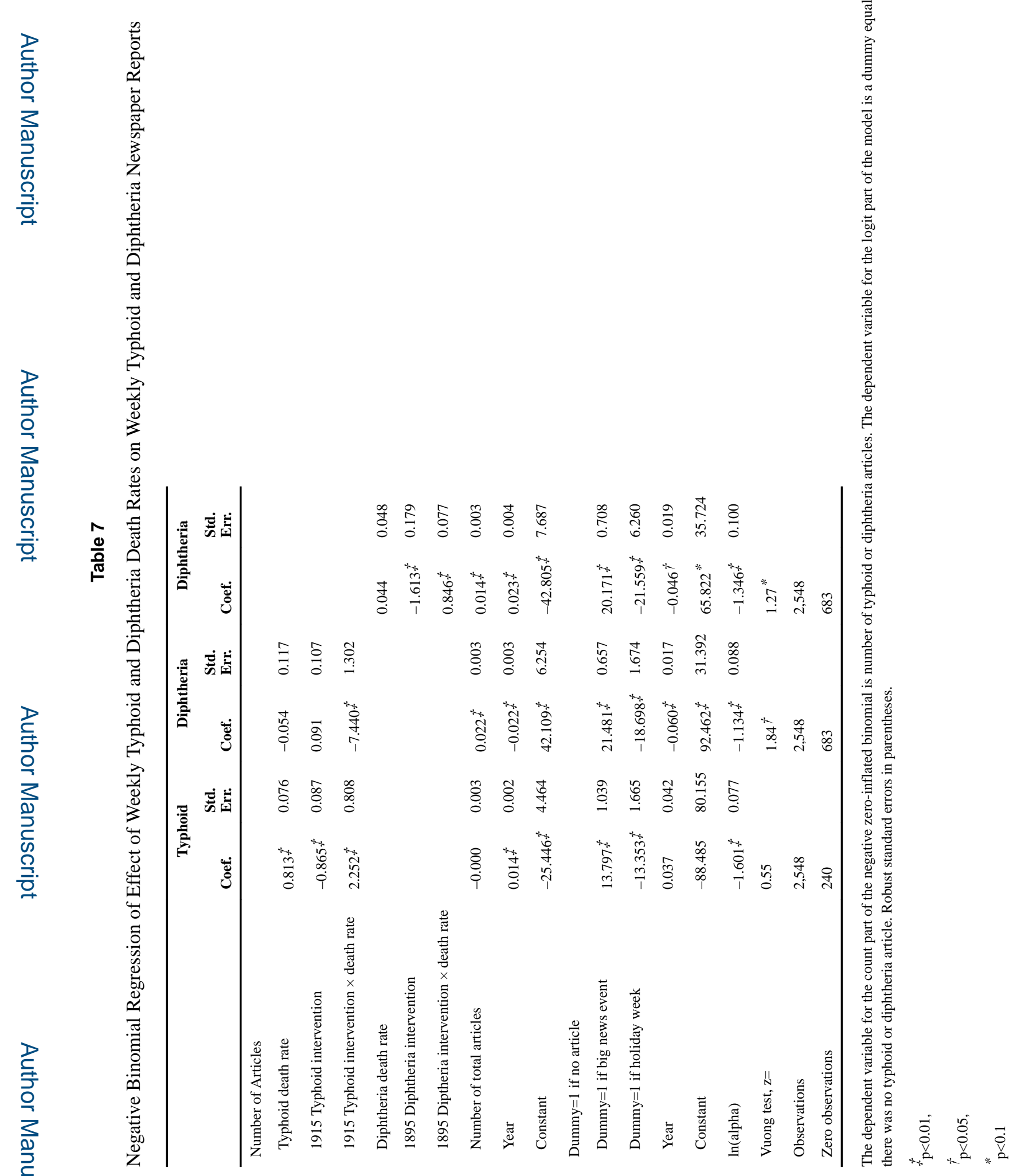


Table 8

Average Case Rate and Case Rate Interaction Marginals from Negative Binomial Regression of Effect of Typhoid and Diphtheria Death Rates on Newspaper Reports

\begin{tabular}{|c|c|c|c|c|}
\hline & $E(y \mid x)$ & $\frac{\partial E(y \mid x)}{\partial d}$ & $\frac{\partial E(y \mid x)}{\partial I}$ & $\frac{\partial^{2} E(y \mid x)}{\partial d \partial I}$ \\
\hline \multicolumn{5}{|l|}{ Regression: } \\
\hline Typhoid articles on typhoid deaths & 3.395 & $\begin{array}{l}5.124 t \\
(1.032)\end{array}$ & ${ }^{-1.033^{*}}$ & $\begin{array}{l}14.670^{t} \\
(4.288)\end{array}$ \\
\hline Diphtheria articles on typhoid deaths & 1.747 & $\begin{array}{l}-5.827 \\
(1.127)\end{array}$ & $\begin{array}{l}-2.291 \\
(0.448)\end{array}$ & $\begin{array}{l}-21.277^{t} \\
(3.725)\end{array}$ \\
\hline Diphtheria articles on diphtheria deaths & 1.751 & $\begin{array}{l}1.343^{\dagger} \\
(0.100)\end{array}$ & $\begin{array}{l}-2.556^{\dagger} \\
(0.290)\end{array}$ & $\begin{array}{l}0.100^{*} \\
(0.194)\end{array}$ \\
\hline
\end{tabular}

Marginals are for the regressions in Tables 7; $d$ is the death rate and $I$ is the intervention (1915 for typhoid and 1895 for diphtheria). Robust standard errors in parentheses.

$F_{\mathrm{p}}<0.01$

$t_{\mathrm{p}}<0.05$,

p $<0.1$.

Marginals were computed following the procedure outlined in Leitgöb (2014). The mean number of total typhoid articles is 3.390. The mean number of total diphtheria articles is 1.749 . The number of observations is 2,548 . 